\title{
AN EVALUATION OF THE \\ HYDROTHERMAL RESOURCES \\ OF THE DESERT HOT SPRINGS \\ REGION, CALIFORNIA
}

CALIFORNIA ENERGY COMMISSION CONSULTANT REPORT

MASTER

OUf FERUARY 1979 


\section{DISCLAIMER}

This report was prepared as an account of work sponsored by an agency of the United States Government. Neither the United States Government nor any agency Thereof, nor any of their employees, makes any warranty, express or implied, or assumes any legal liability or responsibility for the accuracy, completeness, or usefulness of any information, apparatus, product, or process disclosed, or represents that its use would not infringe privately owned rights. Reference herein to any specific commercial product, process, or service by trade name, trademark, manufacturer, or otherwise does not necessarily constitute or imply its endorsement, recommendation, or favoring by the United States Government or any agency thereof. The views and opinions of authors expressed herein do not necessarily state or reflect those of the United States Government or any agency thereof. 


\section{DISCLAIMER}

Portions of this document may be illegible in electronic image products. Images are produced from the best available original document. 
ABSTRACT

The Desert Hot Springs hydrothermal resource demonstrates its Iimited capacity to sustain additional utilization and development. The evaluation incluaed, the delineation of the areal extent, determination of the hyoraulic cheracteristics, calculation of a safe yiela, ano icentificatior of the source of heat.

The $i r e z i$ extent based on well water temperatures and the area enclosed by a $90^{\circ} \mathrm{F}\left(32^{\circ} \mathrm{C}\right)$ isotherm, is about 5.5 square miles. Thirteen aquifer tests were conducted virich indicated the average transmissivity to be 20,000 gaijons per day per foot and the storativity to be $1.15 \times 10^{-4}$, representing an artesian system. Meteorologic and hycuclogic data are used to estimate the components of the hycroiogic buaget for the calculation of the safe yield. The safe yigld is 3,400 acre feet and the safest safe yieid is 2,100 acre feet. The data generated by the fieid investigation is employed in a muitivariate regression analysis to identify the source of heat. The analysis indicated the hydrothermai waters come to surface in the Bind Canyon fault zone beFore entering the Desert Hot Springs area. 
TABLE OF CONTENTS

PREFACE

vii

ACKNOWIEDGEMENTS

Vìi

Chapter

I. INTRODUCTION AND PROJECT OBJECIVIVS

Introduction

Rationale

Review of other Evaluation Projects

Project scope

II. PHYSICAL SETTING OF THE DESERT HOT SPRINGS EEGION

Survey of Previous work

Geology

Climate

Hydrology

Hydrothermal Resources

III. METHOLOLOGY AND RESULTS

Delineation of the Areal Extent Hydrologic Budget Analysis of the Aquifer System

Hydraulic Characteristics of the Aquifer Aquifer Thickness

Aquifer storage Capacity

Direction of Groundwater Movement

IV. STATISTICAI ANALYSIS

V. DISCUSSION OF RESUITS

Areal Extent

Statistical Anaiysis

rydraulic Characteristics of tre Aquifer

Muitiple Aguifer Hypothesis

Hydrologic Budget and saie Yield

Direction of Groundwater Movement 
VI. SUMMARY OF CONCLUSIONS

Areal Extent

Statistical Analysis

Hydraulic Characteristics

Multiple Aquifer Hypothesis

Hydrologic Budget Analysis

Direction of Groundwater Movement

BIBLIOGRAPHY

APPENDIX A

APPENDIX B

64 


\section{IIST CF ILLUSTRATIONS}

Figure

Page

1-1 Physical Setting for the Evaluation of the the Hydrothermal Resources of Desert Hot springs

2-1 Columnar Chart of the Desert Hot Springs Area

2-2 Structure of the Upper Coachella Valley

2-3 Groundwater Subbasins of the Upper Coachella valiey

2-4 Faults of the Desert Hot Springs Region

2-5 Temperature Isotherms $\left({ }^{\circ} F\right)$ in the Desert fot Springs Region

3-1 Temperature-Deptr: Profiles

3-2 Direction of Groundwater Movement, Based on Static Water Levels, 1977

5-1 Changes in Static Water Levels per Year 46

5-2 Direction of Groundwater Movement 49 


\section{IIST OF TABLES}

\section{Table}

Page

3-1 The Hyarologic Buaget

3-2 Estimate of Safe Yield for Desert Hot Springs

3-3 Desert Hot Springs Aquifer Test Data

A-- Desert Hot Springs Prodivt-Moment Coefficients of Correlation for Identification of cause of Heat Anomaly

4-2 Field Data for Regression Analysis 
PREFACE

The evaluation of the hydrothermal resources of Desert Hot Springs was performed in conjunction with jet Propulsion Laboratories. Partial funding was made available through Syd willard of the California Energy Commission and Yukio Nakamira of Jet Propulsion Laboratory.

$v i i$ 
CHAPTER I

INTRODUCTION AND PROJECT OBJECTIVES

\section{Introcuction}

The current energy shortage has stimulated the exploration and development of geothermal resources around the world. A iydrothermal system is a kind of geothermal resource which includes the reservoir, the contained fluid, and a heat source. There are two major types of hyarothermal systems; (1) vapor dominated or dry steam, and (2) liquia dominated or wet steam. Iiquid dominated hydrothermal systems are further aivided into three temperature ranges; (1) those above $302^{\circ} \mathrm{F}\left(150^{\circ} \mathrm{C}\right),(2)$ those between $302^{\circ} \mathrm{F}$ and $194^{\circ} \mathrm{F}\left(90^{\circ} \mathrm{C}\right.$ ), and (3) those below $194^{\circ} \mathrm{F}$ (White, i975). While the vapor dominated and high temperature liquid dominated systems are significant for power generation, the intermediate and low temperature fluids (below $302^{\circ} \mathrm{F}$ ) have potential for use in space heating, agricultural development, product processing, refrigeration, air conditioning, and arying. For this thesis, the term hyarothermal will be used to describe the liquid dominated geothermal systems.

Rationale

The rationale for understanding a hyarothermal 
resource is the same for grounawater. The concept of the hydrothermal system as a renewable resource, comparable to groundwater, is based upon the rate of replenishment by precipitation or stream flow, and the permeability of the soil and other rock materials through which the water must pass.

The groundwater affecting the hydrothermal system cannot be considered a separate phase of the hydrologic cycle as there are many inter-relations between groundwater, surface water, and soil moisture. These inter-relations assume paramount importance in comprehensive planning for the maximum utilization of all water related resources (ASCE, 1971).

The overall unity of the hydrologic cycle, the interrelations of its several phases, and the extensive modifications that man has made in many areas are documented by a wealth of hydrologic studies and reports. Wherever a resource is to be fully employed to meet the increasing requirements for water, a study must be initiated to develop and maintain a continuing inventory that will show. the quantities of water passing through each phase of the hydrologic cycle, and permit periodic accounting of water storage in the soil, in surface reservoirs, and in groundwater systems.

Review of Other Evaluation Projects

The design of the methodology utilized for the Desert Hot Springs region was based on techniques employec for other 
hydrothermal evaiuation projects. An estimation of the areal extent and the various hydraulic characteristics are key features to these assessment studies.

Paft River, Idaho is presentiy undergoing an initial assessment project. The basic aims of the reservoir tests is to evaluate the geometry and hydraulic characteristics of the resource (Narasimhan and others, 1977).

The tests at Raft River consisted of producing fluid from the production well at a controlled rate over proionged periods of time and observing the water pressure changes in the well and in a second observation well.

The Raft River geothermal tests are identical to a groundwater aquifer test except that instead of measuring drawdown, the pressure changes were measured at the well heads. The Raft River project has established that the geothermal reservoir is fairly extensive and significantly permieable.

Further tests and the installation of new wells are needed to complete the evaluation of the resource. The system may demonstrate the capacity to support a potato processing facility.

Susanville, California is another site for a low temperature hydrothermal resoluce assessment. Utilization of natural hot water began about 50 years ago when managers of a lumber mill began drilling for water to 0001 sawing operations. Several wells were drilled but subsequently abandoned because the water was hot. Eventually, the 
thermal water was used to fill the mill pond, keeping it ice free in the winter and thereby extending the mill operating season (Hannah, 1975).

Four hydrothermal wells are currentiy in use with a temperature range from $79^{\circ} \mathrm{F}\left(26^{\circ} \mathrm{C}\right)$ to $120^{\circ} \mathrm{F}\left(49^{\circ} \mathrm{C}\right)$. Pump tests have been performed in these areas to determine the hydraulic characteristics and the extent of the system (Hannain, 1975).

Klamath Falls, Oregon is an area where the hydrothermal resources have been developed for use primarily in space heating. A geothermal gradient of $51^{\circ} \mathrm{F}\left(11^{\circ} \mathrm{C}\right)$ per 1,000 feet has been established; therefore, water sufficient for space heating $\left(113^{\circ} \mathrm{F}\right.$ to $122^{\circ} \mathrm{F}$ ) can be expected to occur at the depths of 2,200 to 2,400 feet. The heat content of this system has been estimated on the basis of the temperature gradient, aquifer characteristics, and an estimation of the area extent.

\section{Project Scope}

The City of Desert Hot Springs is a small desert. community encompassing approximately nine square miles on a gently sloping alluvial fan at the northern end of the Coachella Valley in Riverside County. The City is endowed with low temperature hydrothermal resources in the region.

The evaluation of the Desert Hot Springs hydrothermal resources describes the nature and extent of the resource, and its relationship to the hydrogeology. The objectives 
of the evaluation are to:

(1) delineate the areal extent of the system,

(2) determine the hyaraulic characteristics, and

(3) calculate the safe yield.

The delineation of the areal extent and hydraulic characteristics of aquifers and safe yield is typical for a groundwater investigation and the same techniques are employed for the hydrothermal evaluation.

A computer program was used to calculate correlation coefficients and regression equations for various combinations of relationships. Based on the accumulated data, the computer determined the most likely source of the heat anomaly within the region. 


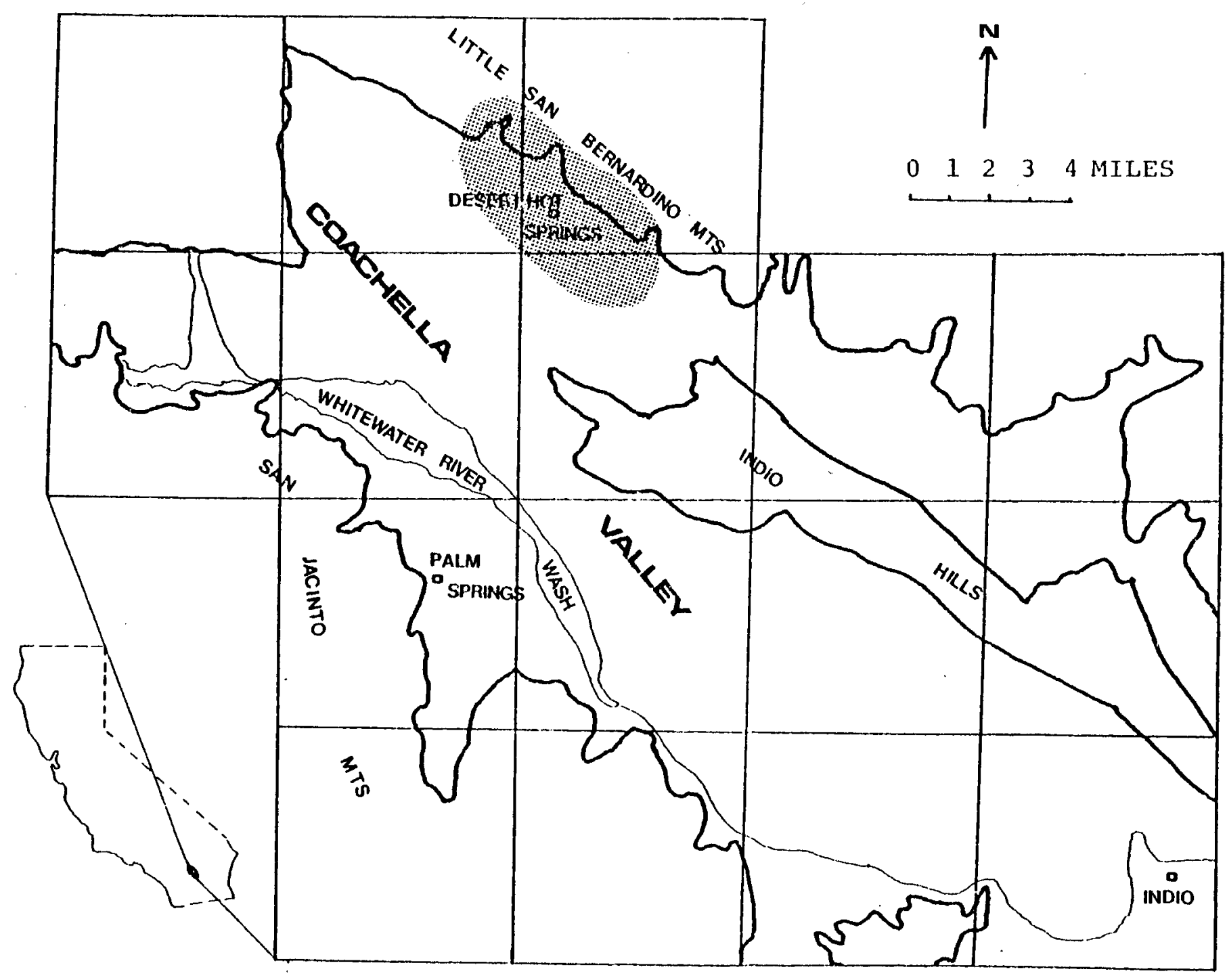

Figure 1-1 Physical setting for the evaluation of the hydrothermal resources of Desert loot Springs, California (Base map from California Department of Conservation).

a) 
CHAPTER II

PHYSICAL SETTING OF THE DESERT HOT SPRINGS REGION

\section{Survey of Previous work}

Most of the existing literature relating to geothermal resources deal with the geology, structure, and hydrology of the area. Blake (1856) was the first geologist to visit and describe the Colorado Desert. Orcutt (1890) discussed the Colorado Desert in general, emphasizing the vicinity of "Salton Dry Lake," but included no geologic map. Mendenhall (1909) studied the groundwater of the Indio region, and briefly described the rocks at the north side of the San Gorgonio Pass. Brown (1923) discussed the geology of the Colorado Desert region and included a geologic map. Dibblee (1954) prepared a map of the Imperial Valley Region including part of the Coachella Valley. Alien (1957) studiea the San Andreas fault zone in San Gorgonio Pass. Richter, Allen, and Nordquist (1958) made a seismic study resulting from earthquakes in the Desert Hot springs area.

Proctor (1958, 1968) has delineated the geology and structure of the Desert Hot Springs area. He discussed the occurrence of the hydrothermai resource under the topic of 
economic geology. Proctor concluded that (1) runoff from the east flank of the San Bernardino Mountains recharges the Desert Hot Springs groundwater basin, mainly by subsurface drainage; (2) the Mission Creek fault zone effectively dams the flow of a large share of the groundwater flowing down the Coachella Valley, and raises the water table close to the surface in the area north of the fauit; (3) the water becomes mineralized and is heated at depth, probably by emanating gases and hydrothermal activity associated with the Mission Creek fault zone; and (4) the groundwater then migrates laterally, principaliy into three pexmeable strata.

The California Department of Water Resources (1964) identified the surface drainage basins, sources of recharge, and airection of groundwater movement in the upper coachella Valley.

A USGS analog study (Tyley, 1971) described the hydrologic characteristics of the upper Coachella valley based on a computer analog analysis. The report summarized (1) where and how imported water can be artificialiy re-. charged, and (2) the impact of artificial recharge and extraction upon the groundwater movement.

Marshali (1975) summarized the geological, hyarological, geochemical, and geophysical data pertaining to the Desert Hot Springs hydrothermal resource. She discussed the need for a hydrological study of the region which would delineate the areal extent, determine safe withdrawal rates, 
locate production well sites, and identify potential sites for artificial recharge or injection of spent hydrothermal fluids.

A research proposal submitted to the City of Desert Hot Springs by Jet Propulsion Laboratories (1976) discusses potential mitiple use application of hydrothermal resources. The overall objective is to develop options that the Department of Energy may exercise in developing low and moderate temperature hydrothermal resources as an economically and environmentally acceptable alternate energy source and enhance the development of a coherent geothermal industry. Dermengian and Peterson (1976) surveyed the use of the resource in the City of Desert Hot Springs. They noted that the City has grown primarily as a result of the "not water."

Russell $(1977,1978)$ presented the results of the pump tests performed in the region. This work involved the delineation of the areal extent, the safe yieid, and potential artificial recharge sites for the Desert yot springs hydrothermal resource.

The extent and characteristics of the hydrothermal resources in the Desert Hot Springs region have not been studied in depth. This thesis attempts to answer many of the questions raised by the work of Proctor $(1958,1968)$, Marshall (1975), and Russeli (1977, 1978). 
Geology

Stratigraphy

The upper Coachella Valley is a rift valley or graben bounded by the San Jacinto and Little San Bernardino Mountains. The san Jacinto range is composed of schists, gneisses, and recrystalized limestone of late Paleozoic age (Figure 2-2). Rocks in the Iittle San Bernaraino Mountains are granites and gneisses of Cretaceous and Paleozoic age. The materials on the valley floor are comprised of cenozoic sediments and vary in age from late Miocene fanglomerates, conglomerates, and lake beds to recent alluvium and sand accumulations (Proctor; 1958, 1968).

Iithology (Eigure 2-1)

The coalescing alluvial fan deposits underlying, the piedmont slopes are the water bearing materials of the Desert Hot Springs subbasin. Proctor $(1958,1968)$ described the fan deposits as primarily coarse-grained and poorly sorted, principally of the ocotillo formation, but also including the overlying recent deposits. The ocotillo conglomerate consists of poorly consoliaated sandstones and conglomerates with thin grey-green streaks and red-brown silts and clays as lens-like interbeds. Recent fanglomerates cover most of the land surface and exposures of the ocotillo conglomerate are present in the basin. Miracle Hill in Desert Hot Springs provide an exposure of the Ocotillo formation. Recent alluvium in the subbasin varies in 
FIGURE 2-1

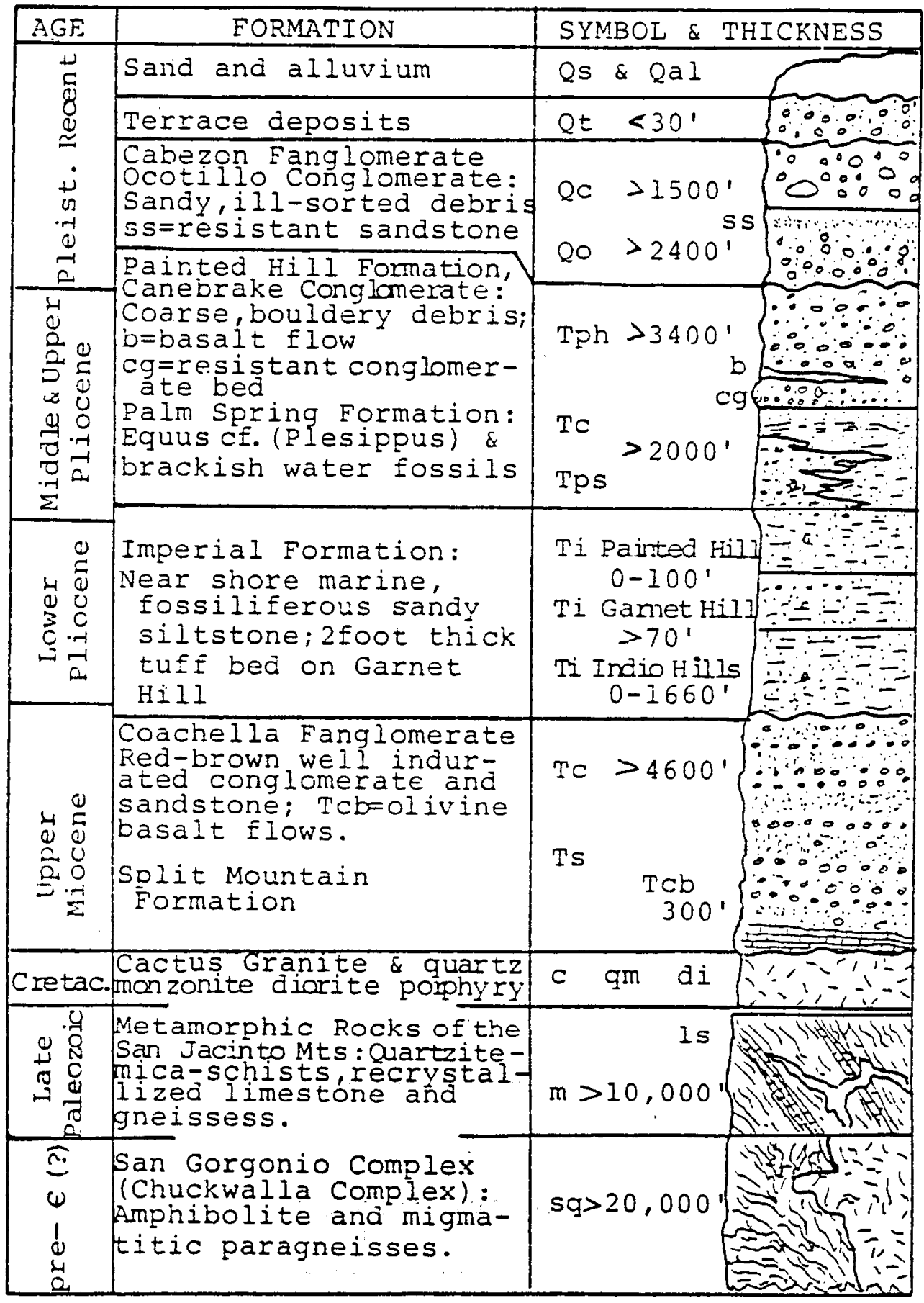

Figure 2-1 Columnar chart of the Desert Hot Springs area (Proctor, 1968). 
tnickness from a thin edge to over 100 feet. The thickness of the underlying ocotillo conglomerate is estimated to be in excess of 700 feet. Drillers' logs commonly describe the material as being cemented.

Structure

The fault system trends in a northwesterly direction and is part of the San Andreas system. The San Andreas fault follows a straight, almost undeviating course from the foothills of the San Bernardino Mountains, across the Coachella valley and into the Indio Hills (Figure 2-2).

The Mission Creek fault, named and first described by Vaugin (1922), is believed to be the most active tectonic feature because of its recent topographic expression and seismological data that relate it to recent earthquakes. The Mission Creek and San Andreas fault merge at a low angle near Biskra Palms in the Indio Hills, 12 miles southeast of the Desert Hot Springs region (Figure 2-2).

The location and direction of movement of the fault is also well known from indirect evidence; such as gravimetric survey results, well depths to static water level, seismic data, and triangulation surveys of the US coast and Geodetic Survey. The Mission Creek fault is an effective barrier to groundwater movement as evidenced by the 150 to 200 foot water level drop from the north side of the fault to the south.

The Banning fault trends northwest on the south side 


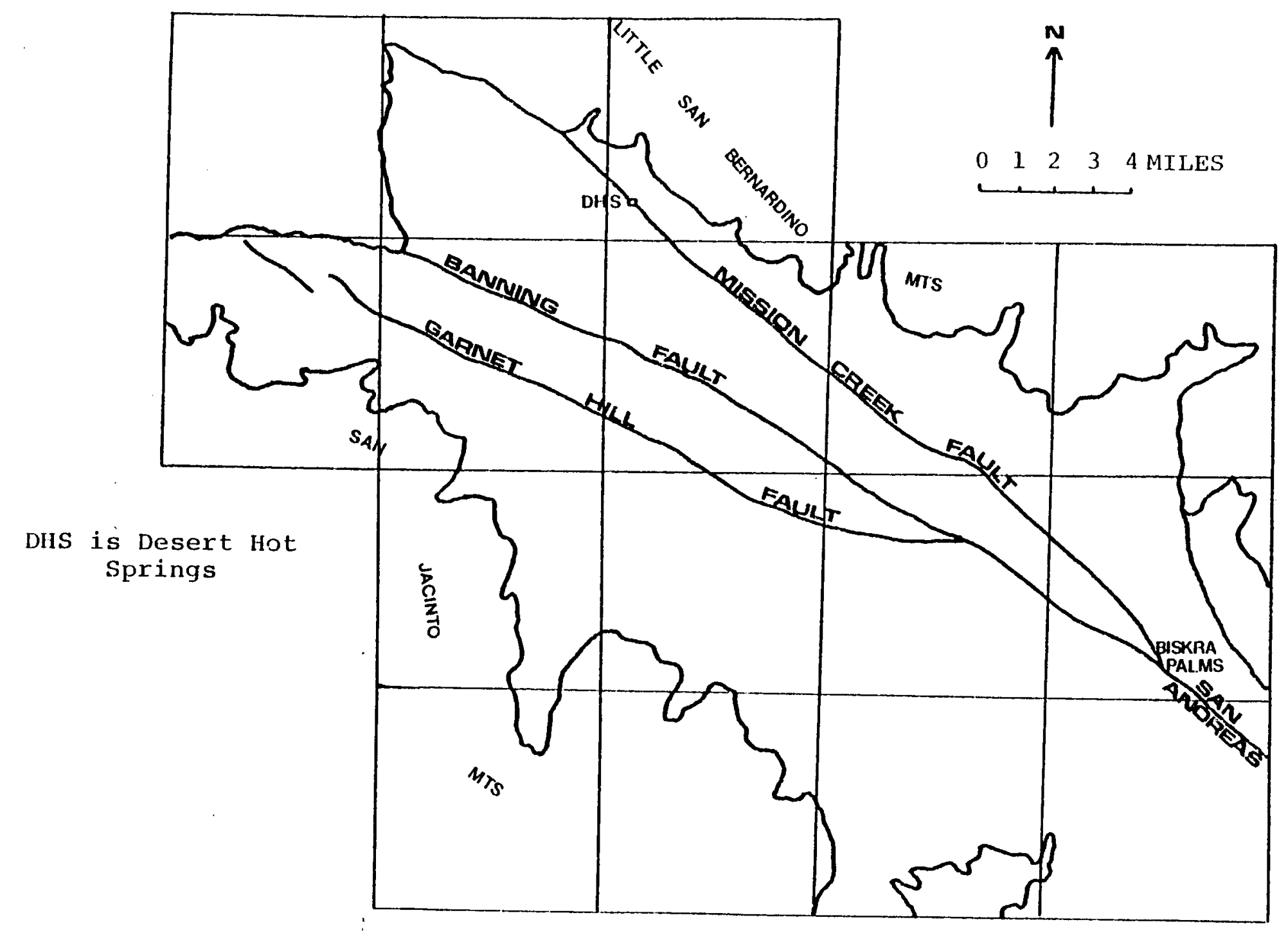

Figure 2-2 Structure of the upper Coachella Valley (DWR, 1964). 
of the Indio Hills, through San Gorgonio Pass. This fault serves as an effective barrier to groundwater movement as evidenced by a 100 to 200 foot decrease in static water level between the Mission Creek subbasin and the Garnet Hill subbasin (Tyley, 1971).

The Garnet Hill fault is parallel to, and 1 1/2 miles south of the San Andreas fault (Figure 2-2). The fault acts as a groundwater barrier, creating about a 100 foot water level decrease between the Garnet Hill subbasin and the Whitewater subbasin (Tyley, 1971).

The Blind Canyon fault, to the north of Desert Hot Springs was located by a trench excavated for the expansion of the Colorado River Aqueduct in 1957 (Figure 2-4). The fault has a 22 incin gouge zone with a westerly dip of $70^{\circ}$, where it cuts gneiss buried by 30 feet of undisturbed alluvium. The relative movement of the fault has not been ascertained; it may continue southward and merge with the Mission Creek fault at depth (Proctor; 1958, 1968).

Buried branches of the Mission Creek fault are plotted south of Miracle Hill inside the Desert Hot Springs. city limits. Proctor (1958) described the Miracle Hill fault as a conjugate fault of the Mission Creek fault. The extension of the Miracle Hill fault is based on the marked alignment of grouncwater contours through Desert Hot Springs. The wells north of the fault are shallower and generally produce hotter water than those to the south. The exact location of this fault is subject to controversy, and 
Eett (1978) states the fault may not have been drawn in the correct location.

\section{Climate}

The climate of the upper Coachella Valley is classified as tropical desert, with mild winters, hot summers, and sparse precipitation falling during the winter months. The winter daily temperatures range from the low $30^{\prime} \mathrm{s}$ to the $80^{\prime} \mathrm{s}$, and light snow falls every few years upon the valley floor. It is not uncommon for the summer temperatures to exceed $110^{\circ} \mathrm{F}$ on a daily basis (Hely and Peck, 1964).

The average annual rainfall varies from 4 inches on the desert floor to 15 inches in the surrounding mountains (Hely and Peck, 1964). There are no perennial streams on the valley floor; water flowing off the mountains infiltrates into the sandy alluvium at the foot of the slopes.

\section{Hvarolegy}

The upper Coachella Valley consists of 4 drainage subbasins delineated by the fault zones (Figure 2-3). Proceeding from west to east there is the whitewater subbasin, the Garnet Hill subbasin, the Mission Creek subbasin, and the Desert Hot Springs subbasin.

The City of Desert Hot Springs lies between the Mission Creek and Desert Hot Springs subbasins. These two areas are separated by the Mission Creek fault running through the southern portion of the city. 


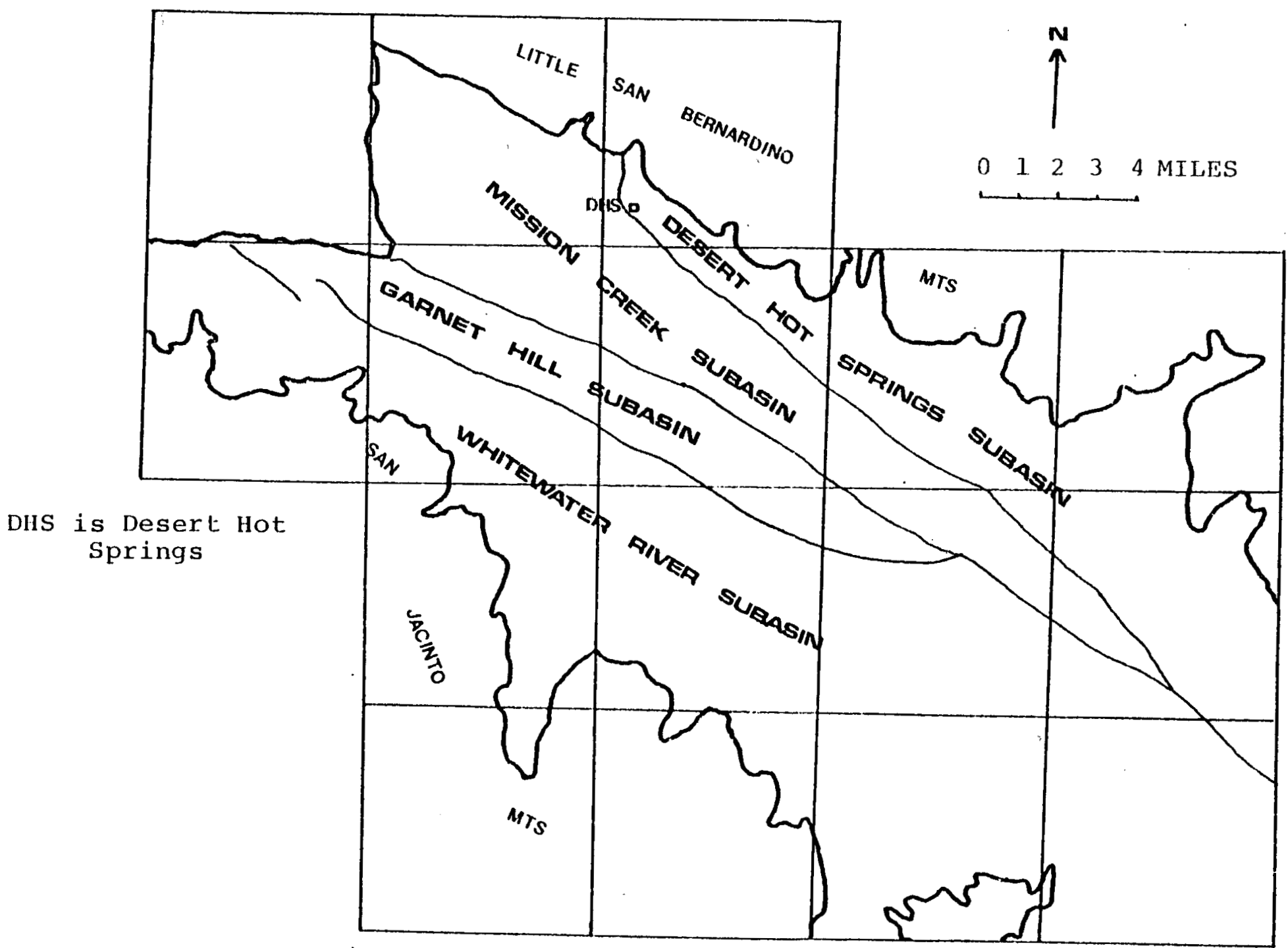

Figure 2-3 Groundwater subbasins of the upper Coachella Valley (Tyley, 1971).

$\stackrel{\mu}{\sigma}$ 
The Desert Hot Springs region is underlain by alluvium in excess of 700 feet and a basement of metamorphic rocks consisting of gneiss, schists, and meta-sediments (Proctor, 1958,1968). The bedrock and alluvium is transversed by the Mission Creek, Miracle Hill, and Blind Canyon faults (Figure 2-4).

Tyley's 1971 study assumed an average transmissivity in the northern portion of the Desert Hot Springs subbasins to be $30,000 \mathrm{gpd} / \mathrm{ft}$ and $2,000 \mathrm{gpd} / \mathrm{ft}$ in the south. The decrease in transmissivity to the south is probably due to more clay material in the aquifer system from the Indio Hills area (Tyley, 1971).

The Mission Creek subbasin is located in the center of the Coachella valley. The transmissivity is approximately 2,000 gpd/ft at the north end, reaching a maximum of 200,000 gpd/ft near North Palm Springs before decreasing to the south (Tyley, 1971). These are approximate values assumed for an analog model study. Tyley (1971) estimated the storativity to be 0.08 in the north and determined that it increased towards the south to a value of 0.18 before.. decreasing at the southernmost end.

Hydrothermal Resources

Approximately 250 wells have been drilled in the region, many less than 300 feet in depth. Temperature isotherms constructed using well log temperature data indicate that the high temperature zones are adjacent to the Mission Creek, Miracle Hill, and Blind Canyon faults. 


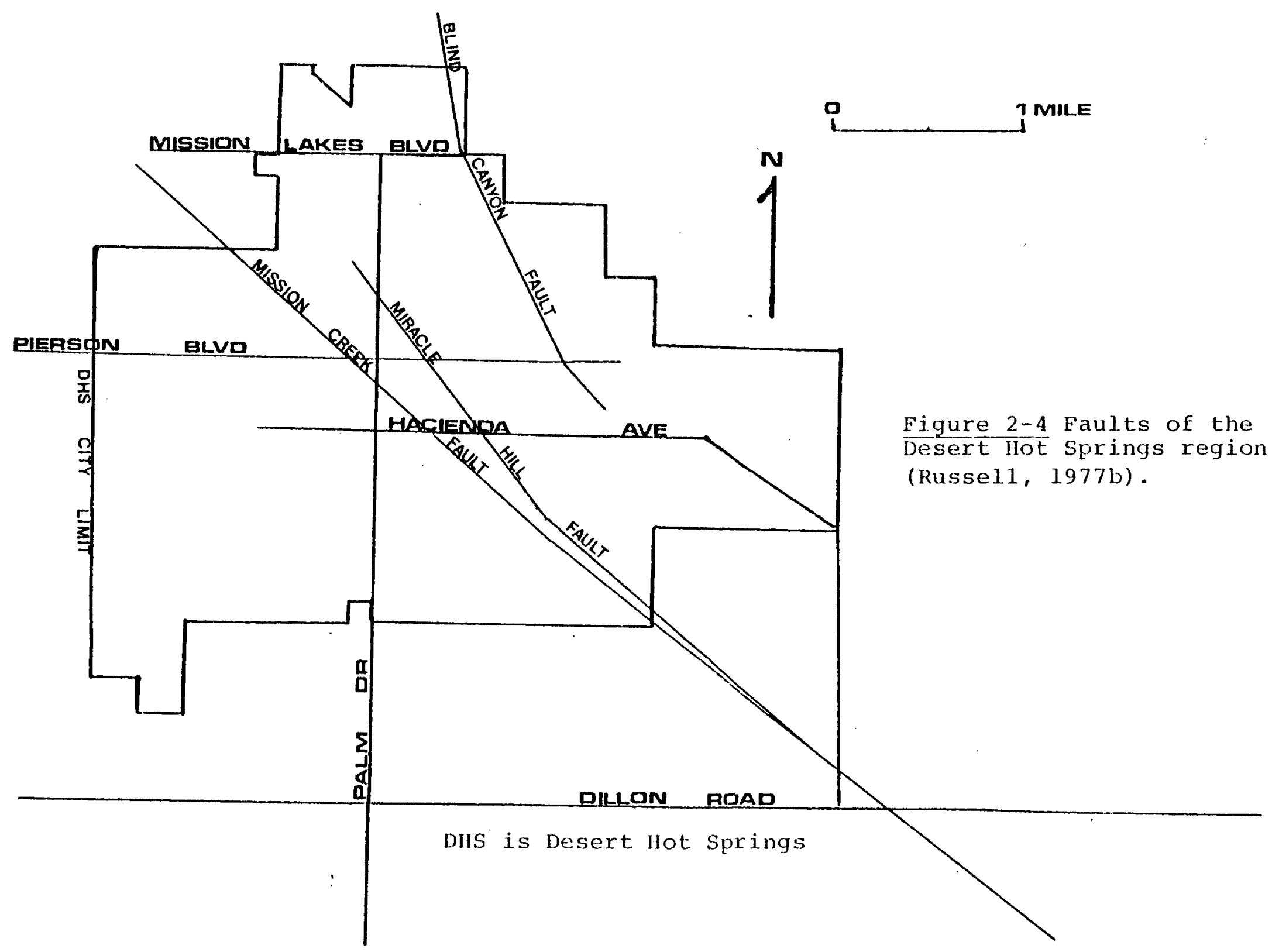


Temperatures on the southwest of the Mission Creek fault are lower, in the $70^{\circ} \mathrm{F}\left(21^{\circ} \mathrm{C}\right)$ to $85^{\circ} \mathrm{F}\left(29^{\circ} \mathrm{C}\right)$ range, while temperatures to the northeast of the fault range from $82^{\circ} \mathrm{F}$ $\left(28^{\circ} \mathrm{C}\right)$ to $208^{\circ} \mathrm{F}\left(98^{\circ} \mathrm{C}\right)$. The highest temperatures are found in the Dillon Road area, located to the southeast of Desert Hot Springs (Figure 2-5). Temperatures within the city limits range up to $180^{\circ} \mathrm{F}\left(82^{\circ} \mathrm{C}\right)$.

Over 150 wells have been drilled within the city limits; most are used for domestic purposes such as heating of swimming pools and whirlpool spas. Water is withdrawn from these wells for several hours once or twice a week. The depth of the wells range from 100 feet to over 700 feet. The deep wells (greater than 500 feet) belong to the Desert Hot Springs County Water District. These wells are no longer employed as the principal source of potable water within the Desert Hot Springs region. They have been considered as hydrothermal wells because the well water exceeds $90^{\circ} \mathrm{F}$. The water district wells are pumped in conjunction with the new wells located to the southwest across the Mission Creek fault (Kibbey, 1978).

The county water district wells were pumped for extended periods at high discharge rates prior to the installation of the wells south of the fault. Over the last ten years, the greatest change'in the static water level for the region has occurred at the sites of the water district wells. 


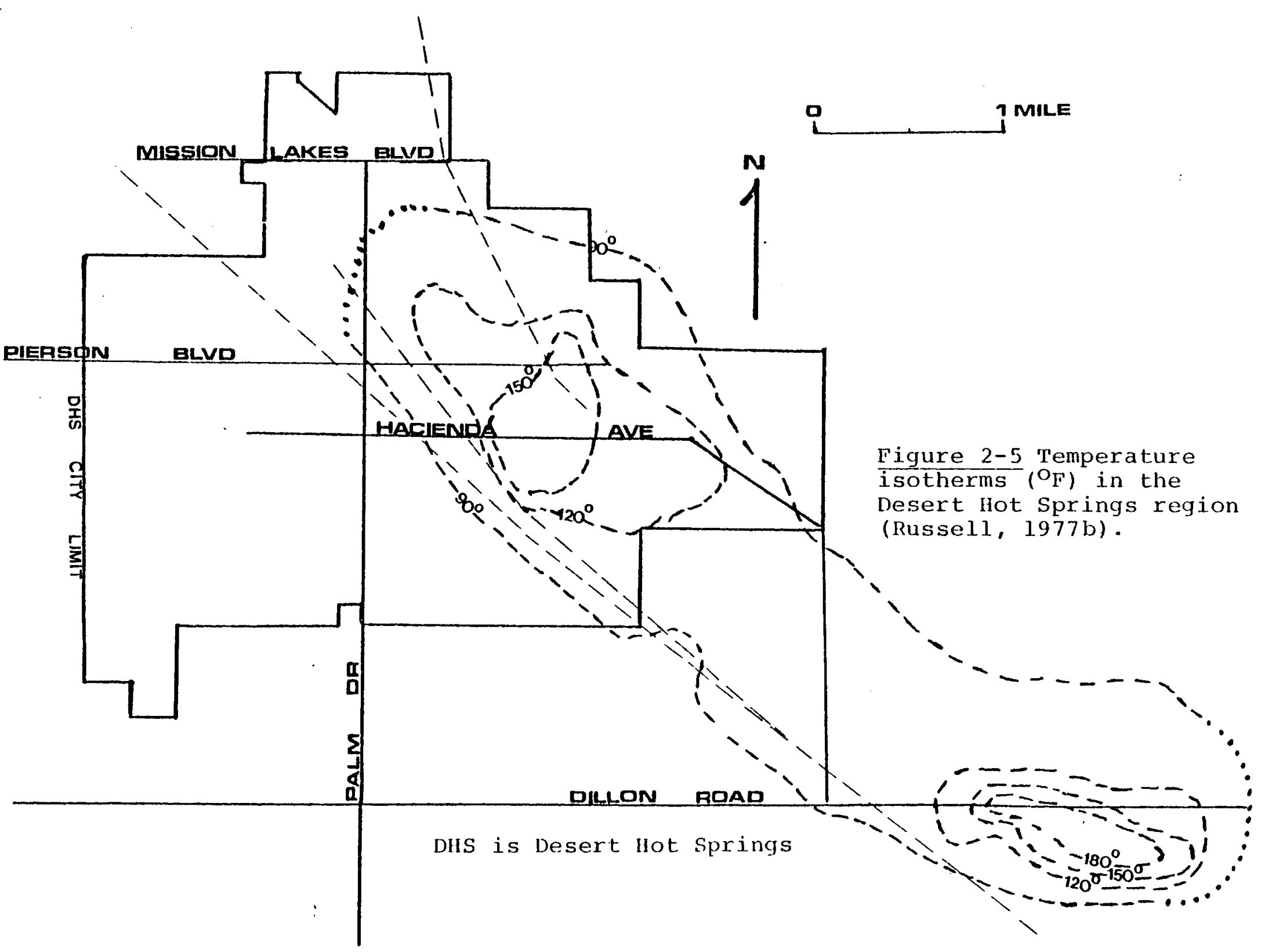

The resource temperature is higher in the Dillon Road area than those in Desert Hot Springs. 
The Dillon Road area has several wells which yield water with temperatures in excess of $180^{\circ} \mathrm{F}\left(82^{\circ} \mathrm{C}\right)$; temperatures in excess of $200^{\circ} \mathrm{F}\left(93^{\circ} \mathrm{C}\right)$ are not uncommon within the vicinity (Figure 2-5).

The well log data associated with the Dillon Road area is limited and consequently no change in static water level has been recorded and may be assumed to be insignificant. 
CHAPTER III

\section{METHODOLOGY AND RESULTS}

In evaluating the hydrothermal resources of Desert Hot Springs, methods were employed similar to those developed for the Raft River, Susanvilie, and the klamath Falls investigations. These included the delineation of the areal extent, determination of the hyaraulic characteristics (transmissivity, storativity), and estimating the safe yield of the system. This chapter describes the methods and results of the investigation.

\section{Delineation of the Areal Extent}

The delineation of the areal extent of the Desert Hot Springs resource is based on the $900 \mathrm{~F}\left(32^{\circ} \mathrm{C}\right)$ temperature isotherm. This minimum is based on the current technology of direct utilization as practiced in many parts of the world including Iceland, New Zealand, Japan, Italy, USSR, and the United States (Iund, 1978). Based on current plans of utilization of the hot water for recreation, spaceheating, and aquaculture in the Desert Hot Springs area, the $90{ }^{\circ} \mathrm{F}$ is considered acceptable for utilizing the hydrothermal resource.

The locations of the hydrothermal wells and their respective temperatures were plotted and isotherms were 
constructed. The temperature data was obtained from well logs maintained by the Coachella valley water District and the Desert Hot Springs County water District. The planimetric measurement of the area enclosed by the $90^{\circ} \mathrm{F}\left(32^{\circ} \mathrm{C}\right)$ isotherm is 5.45 square miles.

A thermister type temperature probe was used to obtain temperature-depth profiles within the well casing at 10-20 feet intervals (Figure 3-1). The profiles (Figure 3-1) were useful in determining if there were significant vertical temperature variations. The four profiles indicate good mixing within the water column and little change in temperature of water from the static water ievel to the bottom of the casing. Hyarologic Budget Analysis of the Aguifer system

To determine the safe yield, the hydrologic equation was employed. This states that all water entering an area during any period of time must either go into storage within the system boundaries, be consumed therein, exported therefrom, or flow out either on the surface or underground during the same period (Table 3-1) (ASCE, 1961).

Hely and peck (1964) analyzed the precipitation, runoff, and evapotranspiration records in the project region from 1930 to 1961. The results compiled by this study are used for the purpose of calculating the safe yield.

Estimates for the depth of precipitation, annual surface runoff, and annual evapotranspiration were obtained 
Tramview Lodge

Lido Palms

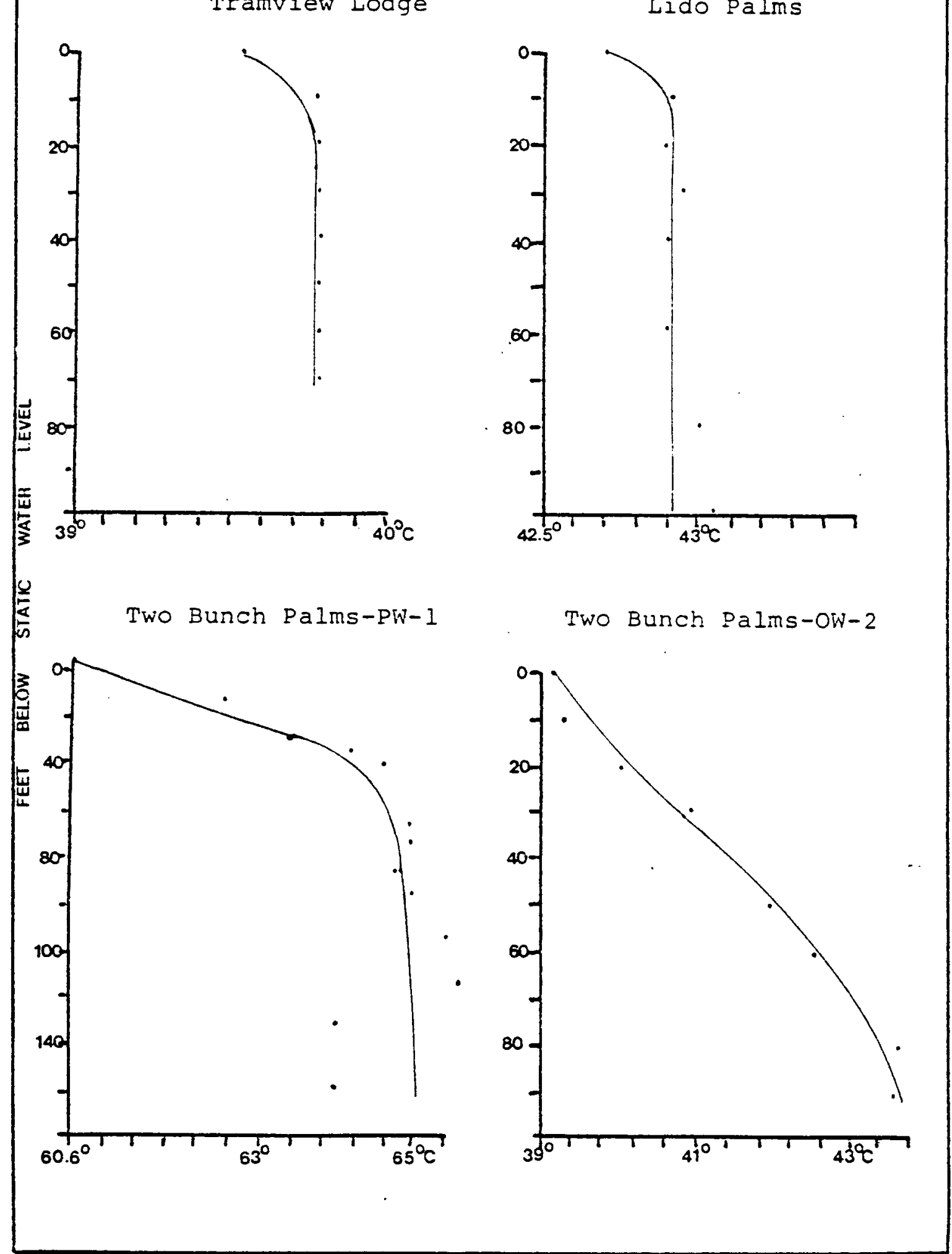

Figure 3-1 Temperature-depth profiles

The profiles indicate good mixing and little change in temperature with depth. 
TABLE 3-1

THE HYDROLOGIC BUDGET

Items of supply

Items of Disposal

1. Surface inflow

2. Subsurface inflow

3. Precioitation on area
1. Surface outflow

2. Subsurface outflow

3. Total evapotranspiration (consumptive use) in area

4. Imported water and sewage 4. Exported water and sewage

5. Decrease in surface storage

5. Increase in surface storage

6. Increase in soil moisture storage

7. Increase in groundwater storage

Total Items of Supply $=$ Total Items of Disposal

Reference: ASCE, 1961 
by planimetering the area enclosed by the respective contours and multiplying by the contour interval. The values are obtained in acre feet. These estimates specify the amount of water available to the groundwater system resulting from precipitation over the surface drainage basin.

The hydrologic budget analysis includes the various items of disposal, surface outflow, exported water and sewage, evapotranspiration, well water removal, and any changes in groundwater storage.

The surface outflow was estimated by determining the net loss from surface inflow in the study area and by subtracting the percentage of precipitation lost due to infiltration.

The calculation of evapotranspiration records is incorporated into the items of disposal. Well water removal estimates were obtained from the USGS analog study (Tyley, 1971). Changes in groundwater storage was estimated by using static water level data from various well sites, such data having been collected over a period of years.

Every component of the hydrologic budget was available except for subsurface outflow. It was estimated by using the following relationship suggested by the ASCE (1961):

$$
\begin{aligned}
\text { SUBOT }= & \text { IS - ID } \\
\text { where: } & \text { SUBOT is subsurface outflow, } \\
& \text { IS is items of supply, and } \\
& \text { ID is items of disposal. }
\end{aligned}
$$

The estimate of subsurface outfiow is equilvalent to the safe yield of the system. 
The probable error involved in these calculations was assumed to be uniformly plus or minus ten percent. For some of these, this assumption may be too severe, for others, it is possibly too generous.

The records accumulated by Hely and Peck (1964) were used to calculate the hycrologic budget. The calculations cf average precipitation and runoff are presented in Table I of Appenaix A. The calculations of total depth of precipitation, surface runoff, evapotranspiration, and infiltration are given in Table 2 of Appendix $A$.

Table 3-2 presents the data for the items of disposal. The safe rield is equal to:

$$
\begin{aligned}
& \begin{aligned}
\text { Safe Yield } & =\text { Items of Supply - Items of Disposal (3.2) } \\
& =8,000( \pm 800)-4,600( \pm 460) \\
& =3,400 \pm 1,260 \text { acre feet/year }
\end{aligned} \\
& \text { The safest safe yield is: } \\
& \text { Safest Safe Yield }=3,400-1,260 \\
& =2,140 \text { acre feet/year }
\end{aligned}
$$

Hydraulic Characteristic of the Aguifer

The inydraulic characteristics provided a measure of the conduit and reservoir functions of the aquifer. These characteristics were determined from the data obtained during the field pumping program. The results of the driller's pump tests were used to supplement the data accumulated by the author. The estimated values were for transmissivity, storativity, boundary conditions, and hydrologic connections. 
TABLE $3-2$

ESTIMATE OF SAFE YIELD FOR DESERT HOT SPRINGS

(Adapted from LADWP - San Fernando Valley Study)

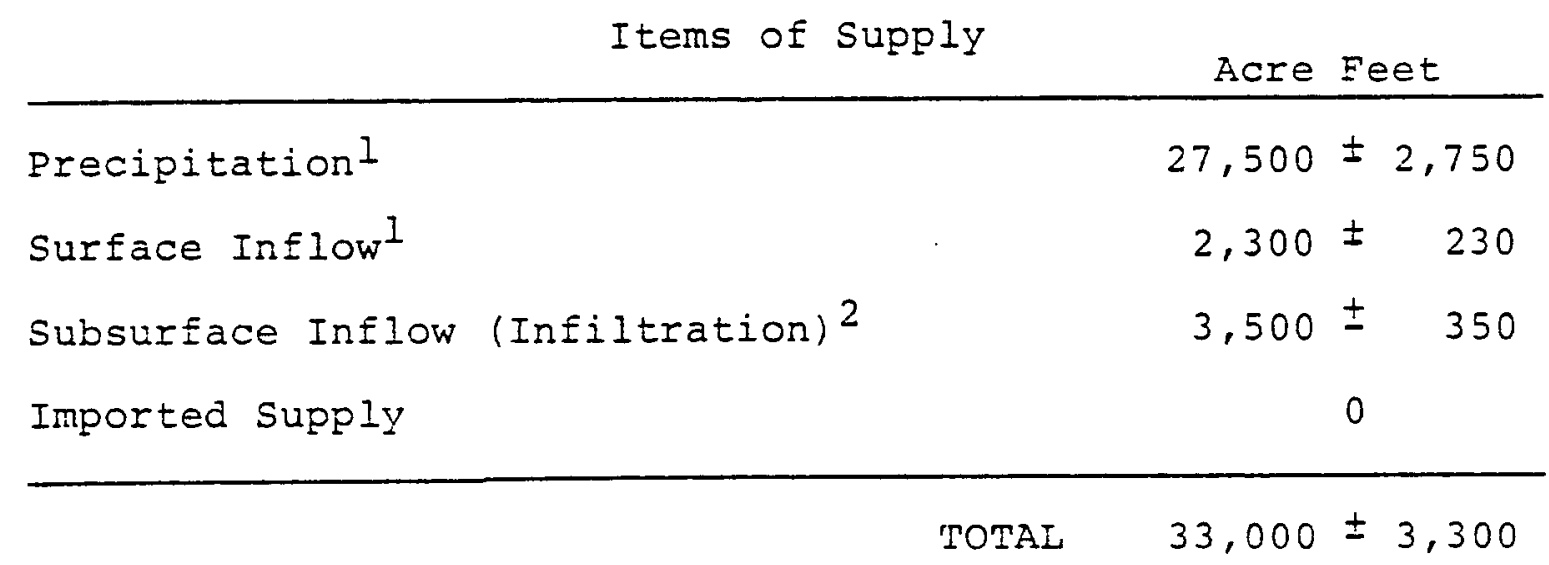

Items of Disposal

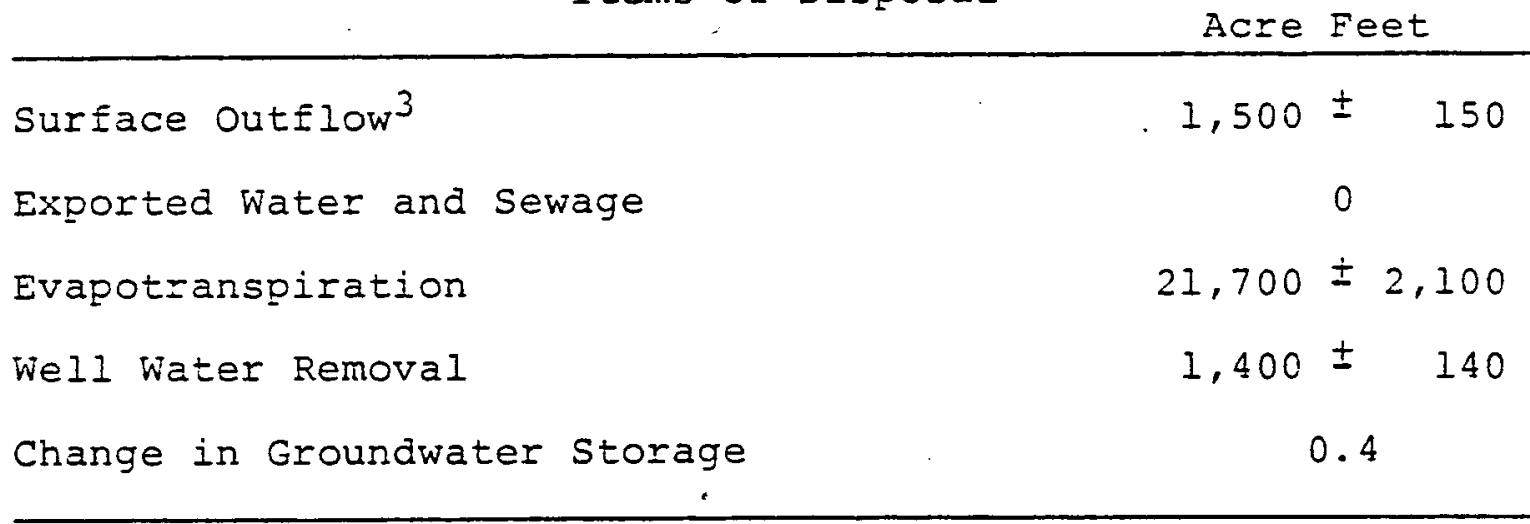

$$
\text { TOTAL } 25,000 \pm 2,500
$$

Safe Yield = Items of Supply - Items of Disposal Safe Yield $=8,000 \pm 5,800$ Acre Feet Der Year Safest Safe Yield $=2,140$ Acre Feet Per Year

$I_{\text {Hely and Peck Study }}$

${ }^{2}$ Infiltration = Precipitation - Surface Runoff - Evapotrans piration

${ }^{3}$ Based on calculation of actual groundwater basin, 13\% infiltration, calculation of precipitation, surface runoff, and evapotranspiration. 
The conduit function, transmissivity ( $T$ ), is a measure of the rate at which water will flow through a vertical strip of the aquifer one foot wide and extending through a full saturated thickness, under a hydraulic gradient of 1.00 (Ferris, 1963).

Values of $T$ in most aquifers range from. less than 1,000 to over $1,000,000$ gallongs per day per foot (gpd/ft) (Ferris, 1963). An aquifer that has a value of $T$ less than 1,000 gpa/ft can supply enough water for domestic wells; where $T$ values are of the order of 10,000 or more well vield can be adequate for industrial, municipal, or irrigation purposes (Johnson, 1968).

The reservoir function, storativity (S), is the volume of water released from storage or taken into storage per unit change in head (Ferris, 1963). Values of $S$ for water table aquifers range from 0.01 to 0.35 ; values for artesian systems vary from 0.00001 to 0.001 (Ferris, 1963).

Boundary effects are either positive or negative depending upon the addition or loss of water via the boundary. Boundary effects are apparent during a pump test by the flattening out or rapid increase in the slope of the time drawdown curve (Johnson, 1968).

Hyarologic connections refer to a pathway through which the water may move: A hydrologic connection between the pumped well and the observation wells should exist to assess the values of $T$ and $S$ (Johnson, 1968). Where the wells are completed in different aquifers, the drawdown in 
one well in response to pumping in another suggests hydrologic connections between aquifers. In Desert Hot Springs this is significantbecause of the alluvial fans that constitute the aquifer material.

The field pumping tests were designed to determine these hydraulic characteristics. Thirteen pump tests were conducted within the Desert Hot Springs and Dillon Road areas.

Water levels in the wells were measured by using a wetted tape and/or electrical sounder. The wetted tape is accurate to 0.01 foot and the electrical sounder is accurate to 0.10 foot. The depth to the pumping water level was measured according to a specified time schedule as presented in Appendix B, Tabie 1 .

The discharge rate was estimated by a volumetric method or by use of an orifice plate. The volumetric method was employed for all but a single test. A 30 gallon cortainer was calibrated for the purposes of the measurements.

The water temperature was measured by using a digital thermister accurate to $0.01^{\circ} \mathrm{C}$. The thermister was lowered into the well and the measurements were taken at 20 foot intervals to the bottom of the well. Figure 3-1 illustrates the temperature-depth profiles.

The data obtained from the pump tests are presented in Table 3-3. The time-drawdown curves that were used to calculate $T$ and $S$ are presented in Appendix $B$. The average measured value for $T$ in the Desert Hot Springs area was $15,000 \mathrm{gpd} / \mathrm{ft}$. The average value for $s$ is $3.0 \times 10^{-4}$. 


\begin{tabular}{|c|c|c|c|c|c|}
\hline & $\begin{array}{r}\text { ST } \\
\mathrm{fe} \\
\mathrm{g}\end{array}$ & $\begin{array}{l}\text { TATIC WATER } \\
\text { LEVEL } \\
\text { Eeet below } \\
\text { wel head head }\end{array}$ & $\begin{array}{c}\text { TRANS- } \\
\text { MISSIVIT'Y } \\
\text { gpd/ft }\end{array}$ & STORATIVITY & $\begin{array}{c}\text { TEMPERAT'URE } \\
\mathrm{O}_{\mathrm{F}}\end{array}$ \\
\hline 1. & Tramview Lodge & 179.3 & 4,000 & ---- & 103.46 \\
\hline 2 . & Lido Palms & 60.3 & 30,000 & $-\cdots-$ & 116.60 \\
\hline 3. & Tradewinds Motel & 185.2 & 6,000 & $-\cdots$ & 102.92 \\
\hline 4. & Stardust Motel & 149.8 & 16,000 & $2.08 \times 10^{-10}$ & 92.84 \\
\hline 5. & Ponce de Leon & 174.2 & 21,500 & $4.21 \times 10^{-7}$ & 100.94 \\
\hline 6. & Lorane Manor & 80.9 & 3,000 & $6.66 \times 10^{-4}$ & 128.00 \\
\hline 7. & Desert Crest Country club* & 85.5 & 70,000 & $1.47 \times 10^{-9}$ & 119.48 \\
\hline \multicolumn{5}{|c|}{ 8. Angel View Crippled Children } & 120.74 \\
\hline 9 . & Kismet Lodge & 86.8 & 1,000 & $2.10 \times 10^{-2}$ & 104.22 \\
\hline & Corkill Trailer Park* & 111.6 & 45,000 & $6.49 \times 10^{-6}$ & 165.56 \\
\hline 11. & Howard Dolyjack* & 175.5 & 12,500 & $2.43 \times 10^{-6}$ & 161.60 \\
\hline & Two Bunch Palms (PW-1) & 6.7 & 33,000 & $\ldots \ldots$ & 148.00 \\
\hline 13. & Two Bunch Palms (OW-2) & 5.9 & 33,000 & $2.95 \times 10^{-4}$ & 109.40 \\
\hline
\end{tabular}

*Dillon Road Area 
The average measured value for $T$ and $S$ for the Dillon Road area is $43,000 \mathrm{gpd} /$ ft and $3.0 \times 10^{-6}$, respectively.

Additional values of $T$ may be approximated by using the equation (Saint, 1977):

$(2,000) \times(Q / s)=$ Predicted $T$

where: $Q / S$ is the Specific Capacity

The average predicted values for $T$ in the Desert Hot Springs area were $13,000 \mathrm{gpd} / \mathrm{ft}$. The Dillon Road area displayed a $T$ value of $33,000 \mathrm{gpd} / \mathrm{ft}$.

The combined averages for calculated and predicted $T$ resulted in an average of $14,000 \mathrm{gpd} / \mathrm{ft}$ for the desert Hot Springs area and $38,000 \mathrm{gpd} / \mathrm{ft}$ for the Dillon Road area.

No boundary conditions were detected during the pumping test program. This was probably due to the short duration of pumping (less than 8 hours).

The Two Bunch Palms pump test indicated that a hydrologic connection did exist between the pumped well (PW-i) and the southern observation well $(0 \mathrm{~W}-2)$. The elevations of the well heads varied slightly but the depth of PW-I was 180 feet and OW-2 was 102 feet. This test was the only.. opportunity during the field investigation to check for a hydrologic connection.

\section{Aquifer Thickness}

The aquifer thickness is known to be greater than 800 feet near the Desert Hot Springs County water District Wells. The DWR (1964) report cross section illustrates the 
system thickness to be approximately 1,000 feet through the Desert Hot Springs area. There are no wells in the region for which well logs are available that indicated the depth to bedrock. Proctor (1958, 1968) did not construct a cross section through the Desert Hot Springs or Dilion Road area; instead the nearest cross section is about 4 miles southeast of the region. This cross section indicates the alluvial ocotillo formation to be approximately 800 feet in thickness. Proctor (1968) was unsure of these values in his cross section as indicated by the question marks. For the purpose of this study, a thickness of 1,000 feet is considered the best estimate.

\section{Aguifer Storage Capacity}

Taking the areal extent and multiplying it by the thickness, the total volume or aquifer material is calculated ( $1.5 \times 10^{11}$ cubic feet). Nultiplying this number by the average storage coefficient for the two areas, the maximum amount of available water in storage that could be yielded at any single point in time is about 50.0 acre feet.

\section{Direction of Groundwater Movement}

Isopotential line for static water levels within the Desert Hot Springs region are shown in Figure 3-2 and indicated the direction of groundwater flow. The data was obtained during the summer of 1977 and supplemented with the static water levels recorded by the well driller for wells less than 4 years old. It was assumed for Figure 3-2 that 


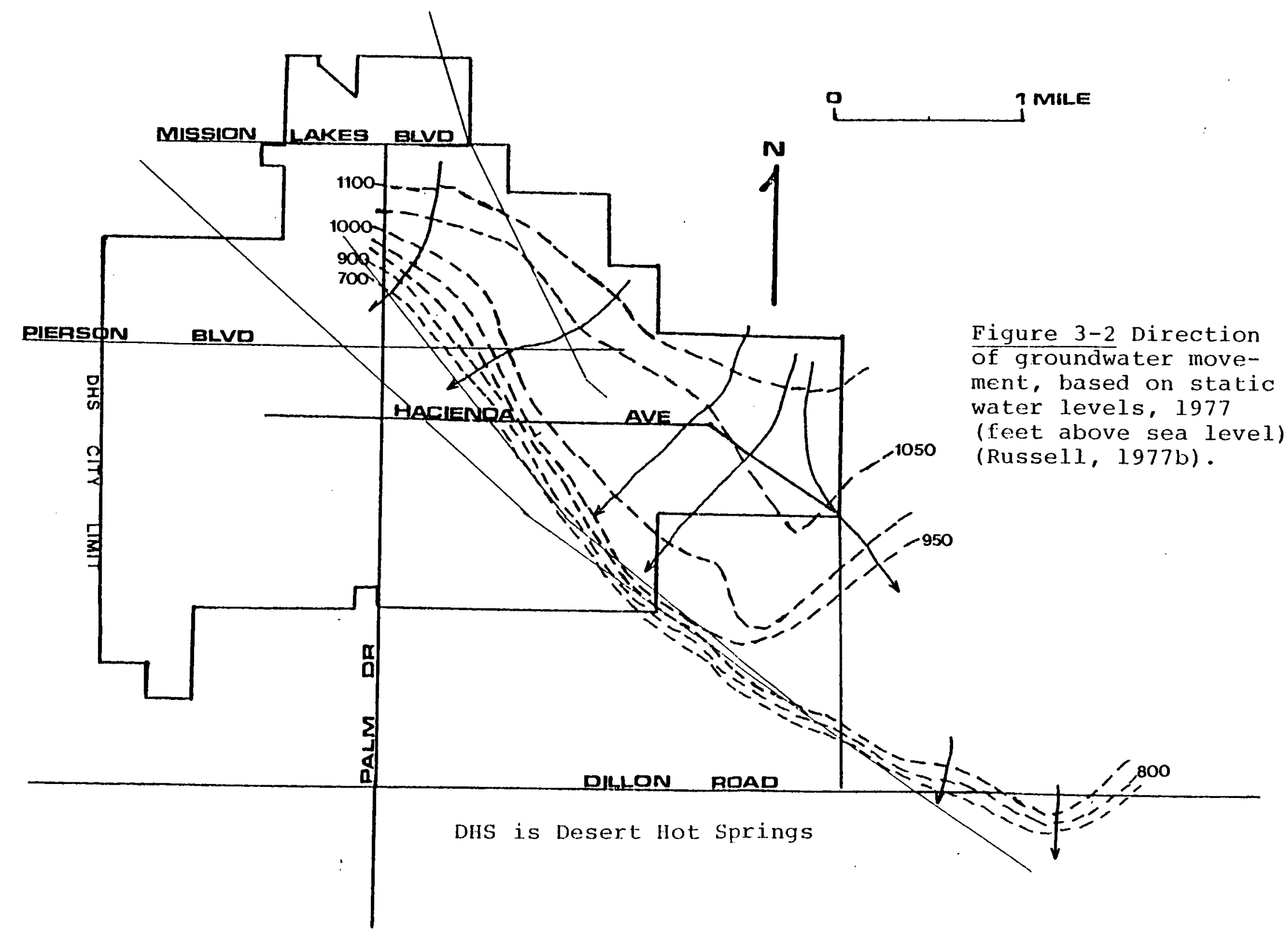

Groundwater enters the region from the Little San Bernardino Mountains. Most groundwater moves toward the Mission Creek fault zone. 
a hydrologic connection does exist over a large portion of the region.

The Desert Hot Springs region receives its water from the Little San Bernardino Mountains located to the northeast. Blind Canyon is a major avenue for hydrothermal recharge to the Desert Hot Springs area.

The majority of groundwater is moving towaras the Mission Creek fault zone within the city limits. To the southeast of the city, the isopotential lines trend northeasterly away from the fault zone, indicating a direction of flow parallel to the Mission Creek fault and towards the Dillon Road area which is receiving some grouncwater from the Desert Hot Springs area. Within the Dillon Road area, the groundwater moves toward the Mission Creek fault. 
CHAPTER IV

STATISTICAL ANALYSIS

The hyarothermal resources of the Desert Hot Springs region are located almost entirely to the north of the Mission Creek fault zone. It has been assumed that the heat anomaly is associated with the Mission Creek, Miracle Hill or Blind Canyon fault zones.

A statistical analysis was conducted to delineate the source of the heat anomaly within the Desert Hot springs region. The analysis only employed the data that had been collected during the field investigation and utilized techniques involving correlation and regression.

Multiple regressions were used to predict the value of a dependent variable, temperature, as a possible function of various independent variables - location with regard to distance from a fault zone, transmissivity, depth of well, and specific capacity. The correlation coefficient was employed to measure the strength of a relationship between two variables.

Temperature as a function of well depth, or distance from a specific fault were the most likely candidates for identification of the heat source. Initial correlations 
were computed for temperature versus well depth (elevation of the bottom of the well) and temperature versus distance from a specific fault zone. The matrix of the correlation coefficients is presented in Table 4-1.

The strongest correlation exists between the distance from the Blind Canyon fault and temperature. The correlation coefficient of 0.5978 accounted for 36 percent of the variation in temperature; a non-linear relationship. Multiple regressions were performed to determine how temperature varied as a function of distance from the fault zones and well depth. This series of regression was based on the data compiled in Table 4-2. The strongest correlation to temperature was the distance from the Bind Canyon fault zone and well depth.

The equation was modified to include a third variable to account for any relationship between elevation and distance from the Blind Canyon fault. The coefficient of correlation increased to 0.9759. By entering the values into the equation, it becomes:

Temperature $\left({ }^{\circ} \mathrm{C}\right)=-36.5434+0.093 \mathrm{x}_{\mathrm{i}}+161.631 \mathrm{x}_{2}-0.196 \mathrm{x}_{3} \cdot(4.1)$ where:

$\mathrm{x}_{1}$ is well depth, in feet,

$\mathrm{x}_{2}$ is distance from the Blind Canyon fault, in miles,

$x_{3}$ is the interrelationship formed by the product of $\mathrm{x}_{1}$ and $\mathrm{x}_{2}$.

The equation is valid within a limited range of values. The limits of the equation are: 
TABLE $4-1$

DESERT HOT SPRINGS PRODUCT-MOMENT COEFFICIENTS OF CORRELATION FOR IDENTIFICATION OF CAUSE OF HEAT ANOMAIY

\begin{tabular}{|c|c|c|c|c|c|}
\hline & Temp. & Elev. & MissCr. & MirHIl. & BlindCyn. \\
\hline Pemperature & 1.0000 & 0.1253 & -0.1848 & 0.1109 & -0.5978 \\
\hline Elevation & 0.1253 & 1.0000 & 0.1469 & 0.1912 & -0.0668 \\
\hline $\begin{array}{l}\text { Mission Cr. } \\
\text { (distance) }\end{array}$ & -0.1848 & 0.1469 & 1.0000 & 0.8194 & 0.1849 \\
\hline $\begin{array}{l}\text { Miracle Hill } \\
\text { (distance) }\end{array}$ & 0.1109 & 0.1912 & 0.8194 & 1.0000 & -0.2727 \\
\hline $\begin{array}{l}\text { Blind Cyn. } \\
\text { (distance) }\end{array}$ & -0.5978 & -0.0668 & 0.1849 & -0.2727 & 1.0000 \\
\hline
\end{tabular}


TABJE 4-2

\begin{tabular}{|c|c|c|c|c|c|c|c|c|c|}
\hline \multirow{2}{*}{$\begin{array}{c}\begin{array}{c}\text { Observation } \\
\text { Number }\end{array} \\
1\end{array}$} & \multicolumn{3}{|c|}{$\begin{array}{c}\text { Well } \\
\text { Number }\end{array}$} & \multirow{2}{*}{$\frac{\begin{array}{c}\text { We11 Water } \\
\text { Temp. }\left({ }^{\circ} \mathrm{C}\right)\end{array}}{40.12}$} & \multirow{2}{*}{$\begin{array}{c}\text { Well Botton } \\
\begin{array}{c}\text { Elevation } \\
\text { Feet }\end{array} \\
900\end{array}$} & \multicolumn{2}{|c|}{ 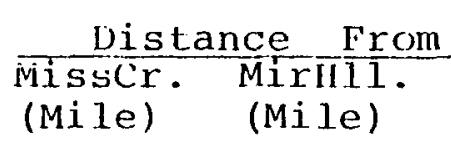 } & $\frac{\text { Well }}{\text { BlindCyn. }}$ & $\begin{array}{l}\quad \text { Product } \\
\text { (Blindcyn) } \\
\text { (Elevation) }\end{array}$ \\
\hline & $2 / 5$ & 32 & $\mathrm{R} 1$ & & & 0.318 & 0.205 & 0.273 & 245.70 \\
\hline 2 & $2 / 5$ & 32 & $\mathrm{C}$ & 49.30 & 965 & 0.681 & 0.408 & 0 & 0 \\
\hline 3 & $2 / 5$ & 32 & $\mathrm{~K}$ & 53.60 & 920 & 0.590 & 0.408 & 0.022 & 20.24 \\
\hline 4 & $2 / 5$ & 30 & $\mathrm{~K}$ & 38.25 & 869 & 0.635 & 0.227 & 0.681 & 591.79 \\
\hline 5 & $2 / 5$ & 30 & $\mathrm{~K} 3$ & 33.80 & 1119 & 0.590 & 0.205 & 0.590 & 660.21 \\
\hline 6 & $2 / 5$ & 30 & $\mathrm{~K} 10$ & 39.40 & 902 & 0.681 & 0.273 & 0.590 & 532.18 \\
\hline 7 & $2 / 5$ & 32 & $\mathrm{E}$ & 47.00 & 930 & 0.363 & 0.091 & 0.273 & 253.89 \\
\hline 8 & $2 / 5$ & 30 & K7 & 39.70 & 892 & 0.636 & 0.273 & 0.590 & 526.28 \\
\hline 9 & $2 / 5$ & 32 & Gl & 74.37 & 1180 & 0.590 & 0.363 & 0 & 0 \\
\hline
\end{tabular}

MissCr. is Distance from Mission Creek Fault

MirHll. is Distance from Miracle Hill Fault

BlindCyn. is Distance from Blind Canyon Fault

FJELD DATA FOR REGRESSION ANALYSIS 
(1) Temperature... $80^{\circ} \mathrm{F}\left(30^{\circ} \mathrm{C}\right)$ to $167^{\circ} \mathrm{F}\left(75^{\circ} \mathrm{C}\right)$

(2) Elevation of the bottom of the well...... $850 \mathrm{ft}$ to $1200 \mathrm{ft}$.

(3) Distance from the Blind Canyon fault ....... . 0 to $0.70 \mathrm{mile}$

T t-test was used to determine the strength of the relationship between temperature and each independent variable (depth, distance, and the interrelationship). At the 90 percent level, the hypothesis that no relationship exists between temperature and the independent variables would be rejected.

The statistical analysis has related the temperature anomaly to:

(1) well depth (elevation of the bottom of the well),

(2) distance from the Blind Canyon fault, and

(3) the interrelationship of well depth and distance.

These conclusions indicated that the heated hydrothermal waters come to surface in the Blind Canyon fault zone before entering the Desert Hot Springs area. Some of the heated water from the Blind Canyon fault may enter the Dillon Road area but it is not responsible for the high temperatures found in that area. It appears that separate avenues for the travel of heated water exist in the Desert Hot Springs and Dillon Road areas. 


\section{CHAPTER V}

\section{DISCUSSION OF RESULTS}

The results generated during the field investigation and statistical analysis have specific implications regaraing the hydrothermal resources of the Desert Hot Springs region. This chapter will evaluate the results and discuss their implications. The following items shall be considered:
(a) the areal extent,
(b) the statistical analysis and delineation of the heat source,
(c) the hydraulic characteristics and storage capacity,
(d) the multiple aquifer hypothesis,
(e) the hyarologic budget and safe yield, and
(f) the direction of groundwater movement.

\section{Areal Extent}

The areal extent of the Desert Hot Springs hydrothermal resource is approximately 5.5 square miles. The majority of the hydrothermal area is located to the northeast of the Mission Creek fault zone which serves as a southern boundary for the hydrothermal resource. The areal extent is essentially identical to that estimated by Proctor $(1958,1968)$. 
The temperature data for delineating the areal extent was obtained from about 100 wells scattered in the Desert Hot Springs and Dillon Road areas. Well data was not available for the northwest or southeast portions of the region where the $90^{\circ} \mathrm{F}$ isotherm is depicted by a dotted line (Figure $3-1)$

The Dilion Road area has water of higher temperatures than those found in the Desert Hot Springs area. Two different avenues of heat may exist for the Dillon Road and Desert Hot Springs areas. The isotherms indicate that the Dillon Road and Desert Hot Springs areas are joined by an area of relatively low temperatures $\left(90^{\circ}-120^{\circ} \mathrm{F}\right)$; while temperatures in the Desert fot Springs area reach $175^{\circ} \mathrm{F}$, and those in the Dilion Road area exceed $200^{\circ} \mathrm{F}$.

Changes in the temperature of the well water over a period of years would affect the correct placement of the isotherms. The well water temperatures of 15 wells were measured to determine if any changes had occurred since the well had been installed. The temperatures had remained within $5^{\mathrm{C}} \mathrm{F}$ for all but one, the Desert crest well, where the well water had decreased about $15^{\circ} \mathrm{F}$ since 1963 , This was the only well in the region that had been pumped 24 hours per day and may hve been affected by a lower temperature boundary.

\section{Statistical Analysis}

The averue of travel of heated water for the Desert Hot Springs area seems to be the Blind Canyon fault zone. 
The regression entails the prediction of temperature as a function of well depth, distance from the Blind Canyon fault, and the interrelationship of the well depth and distance. Wells of greater depth and closer to the Blind Canyon fault display higher temperatures.

This conclusion is contrary to the results of Proctor's work $(1958,1968)$. His work has attributed the cause of the heat anomaly to the Mission Creek fault where the water becomes mineralized and is heated at depth migrating laterally into the system away from the fault. His conclusion seems to be based on the isotherms which are confined to the north side of the fault.

The direction of groundwater flow contradicts Proctor's statement of lateral movement (Figure 3-2). The Blind Canyon fault is located in an area of recharge where heated water could surface and affect the Desert Hot Springs area.

The cracks and fissures associated with the fault zone serve as an avenue for transporting the heated groundwater from depth towards the surface. The regression analysis" implies the Blind Canyon fault is such an avenue.

This fault cannot be responsible for the high temperatures found in the Dillon Road area. Groundwater moving away from the fault zone would enter the Desert Hot Springs area from the northeast. Most of this water would move towards the Mission Creek fault and some would flow towards the Dillon Road area parallel to the Mission Creek fault. 
The hot water found in the Dillon Road area cannot have travelled from the Desert Hot Springs area. This implies a separate avenue of hot water recharge for the Dilion Road area.

Hydraulic Characteristics of the Aguifer

The results of the aquifer tests were used to determine the hydraulic characteristics of the hydrothermal system. The average value for transmissivity in the Desert Hot springs area was $15,000 \mathrm{gpd} / \mathrm{ft}$, and 43,000 gpd/ft for the Dillon Road area. The values for transmissivity in the Desert Hot springs area varied between 1,000 and $30,000 \mathrm{gpd} / \mathrm{ft}$ while the Dillon Road area ranged from 12,500 to 70,000 gDd/ft. The variation in results may be due to the lithology, well completion, and/ or experimental conditions. The average storage coefficient for the Desert Hot Springs and Dilion Road areas were $3.0 \times 10^{-4}$ and $3.0 \times 10^{-6}$, respectively.

These values indicate the resource is artesian with the potential for municipal development. The drawdown in the wells could be substantial under artesian conditions and high rates of withdrawal.

Data pertaining to boundary conditions was not ascertained during the aquifer tests. The aquifer tests were probably at too low a discharge rate and too short a duration. The Desert Crest well may have encountered a temperature boundary condition but no data was available to document the circumstance. 
The static water levels from the field investigation and the Desert Hot Springs County water District were used to construct Figure 5-1. The figure illustrates the greatest change in static water level per year occurred around the county water district wells. Figure 5-1 was constructed without regard to well depth, which ranged from 100 feet to over 700 feet. This figure indicates that a hydrologic connection does exist over a large portion of the region and a single aquifer interspersed with low permeability lenses dominates the region.

The estimated storage of the Desert Hot Springs region was based on the data of the areal extent, hydraulic characteristics, and thickness of the hydrothermal system. Sasea on these results, the storage capacity is approximately 500 acre feet. The estimate assumes that tine aquifer thickness is 1,000 feet, the areal extent is 5.15 square miles, and the average storage coefficient is $1.5 \times 10^{-4}$. Multiple Aquifer Hypothesis

A multiple aquifer hypothesis was presented by proctor $(1958,1968)$ who based it on a statement by Tarbutton, a Iocal well driller. The hypothesis has been accepted as a fact (Dermengian, 1976) but no data has been found to substantiate the presence of three horizontal strata in the project region.

Seven cross sections were constructed from well logs to identify the three horizontal strata. None of these cross sections gave an indication of multiple layered aquifers, but they did indicate that the well driller often recorded 


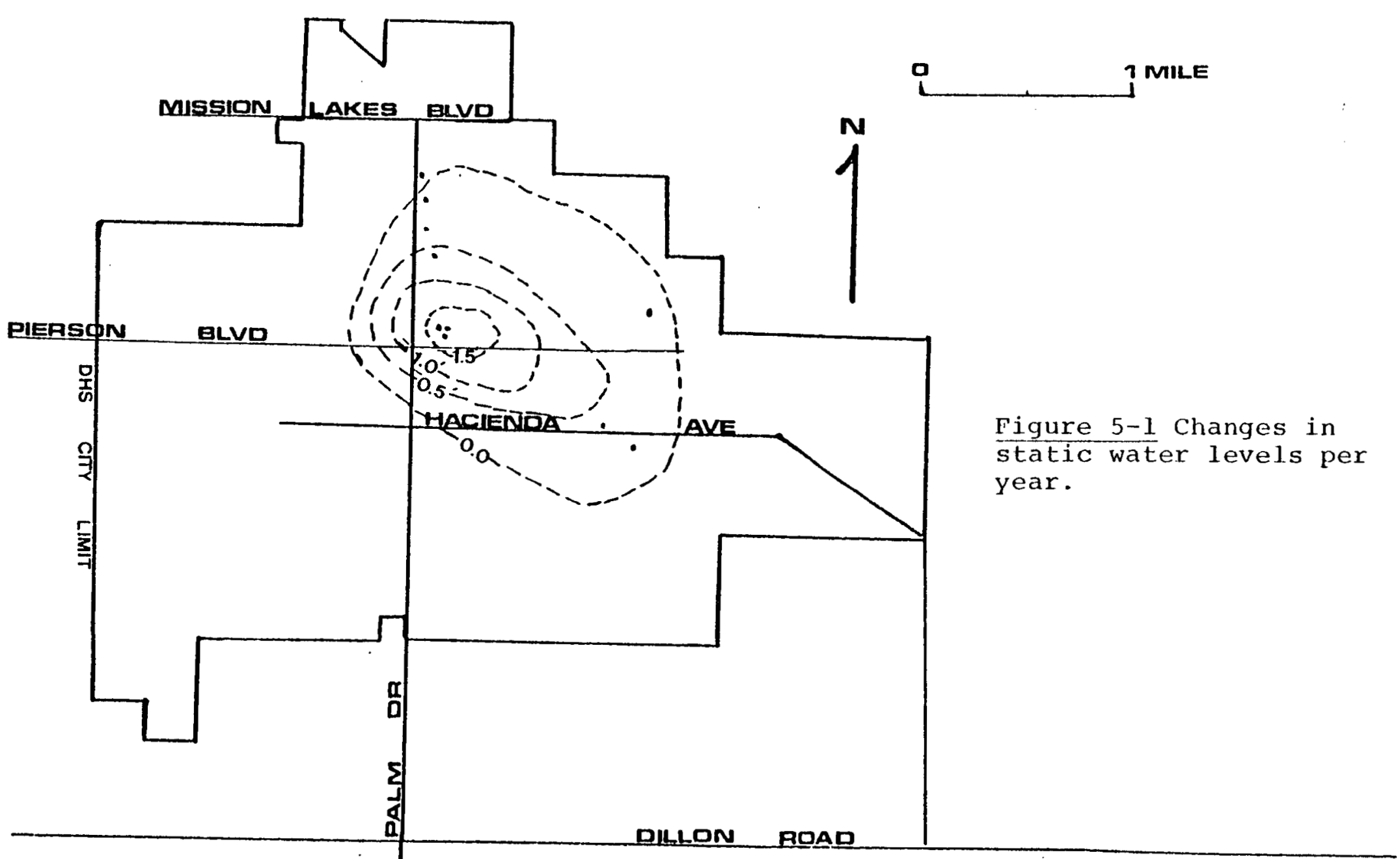

DHS is Desert Hot Springs

The greatest change in static water level occurred at the county water district wells $\left(>500^{\prime}\right)$ and affected the surrounding wells (<300') indicating a hydrologic connechion. 
water entering the well two to three times during the construction process. A well driller may have considered such an occurrence to infer the existence of multiple aquifers.

The city is located over alluvial fan material that has been washed down from the Little San Bernardino Mountains. Clay lenses and other low permeability materials are dispersed through the more permeable layers found in the alluvail fans. This supports the theory of a single aquifer, interspersed with low permeability lenses of a limited areal extent.

Hyarologic Budget and Safe Yield

The estimated figure for the safe yield of the region is 3,400 acre feet. The estimate was based on a 30 year record of the meteorologic and hydrologic data for the Colorado Desert.

The safe yield was calculated by adapting a method employed by the Los Angeles Department of Water and Power (LADWP) for an inventory of the San Fernando Valley. The available data for the Desert Hot Springs region was similar to the data used by the LADWP to determine the safe yield of the San Fernando Valley.

Safe yield estimates can also be based on changes in groundwater storage for the system. This technique requires accurate information regarding fluctuations in static water levels but such data does not exist for the Desert Hot Springs region. 
The usefulness of the hydrologic equation depends on how accurately each item can be estimated. The probable error involved in each component of the equation was assumed to be plus or minus 10 percent. The safest safe yield of 2,100 acre feet should be considered with regard to magnitude rather than an exact figure.

\section{Direction of Groundwater Movement}

The major area of recharge for the region is the Little San Bernardino Mountains located to the northeast of the Desert Hot Springs subbasin. Most of the groundwater moves toward the Mission Creek fault zone in the Desert Hot Springs and Dillon Road areas. Some groundwater flows parallel to the Mission Creek fault from the Desert Hot Springs area to the, Dillon Road area (Figure 5-2). Groundwater withdrawal in the Desert Hot Springs area will influence the Dillon Road area. The Mission Creek fault zone is an area of discharge for the Desert Hot Springs and Dilion Road areas.

The hydraulic gradient (I) decreases to the southeast of the Desert Hot Springs area. This indicates that if the rate of flow $(Q)$ remains constant then the permeability (K) or cross-sectional area (A) must increase (Darcy's Law; $Q=K(A)$. Further work is required to identify the cause of the decrease of groundwater gradient. 


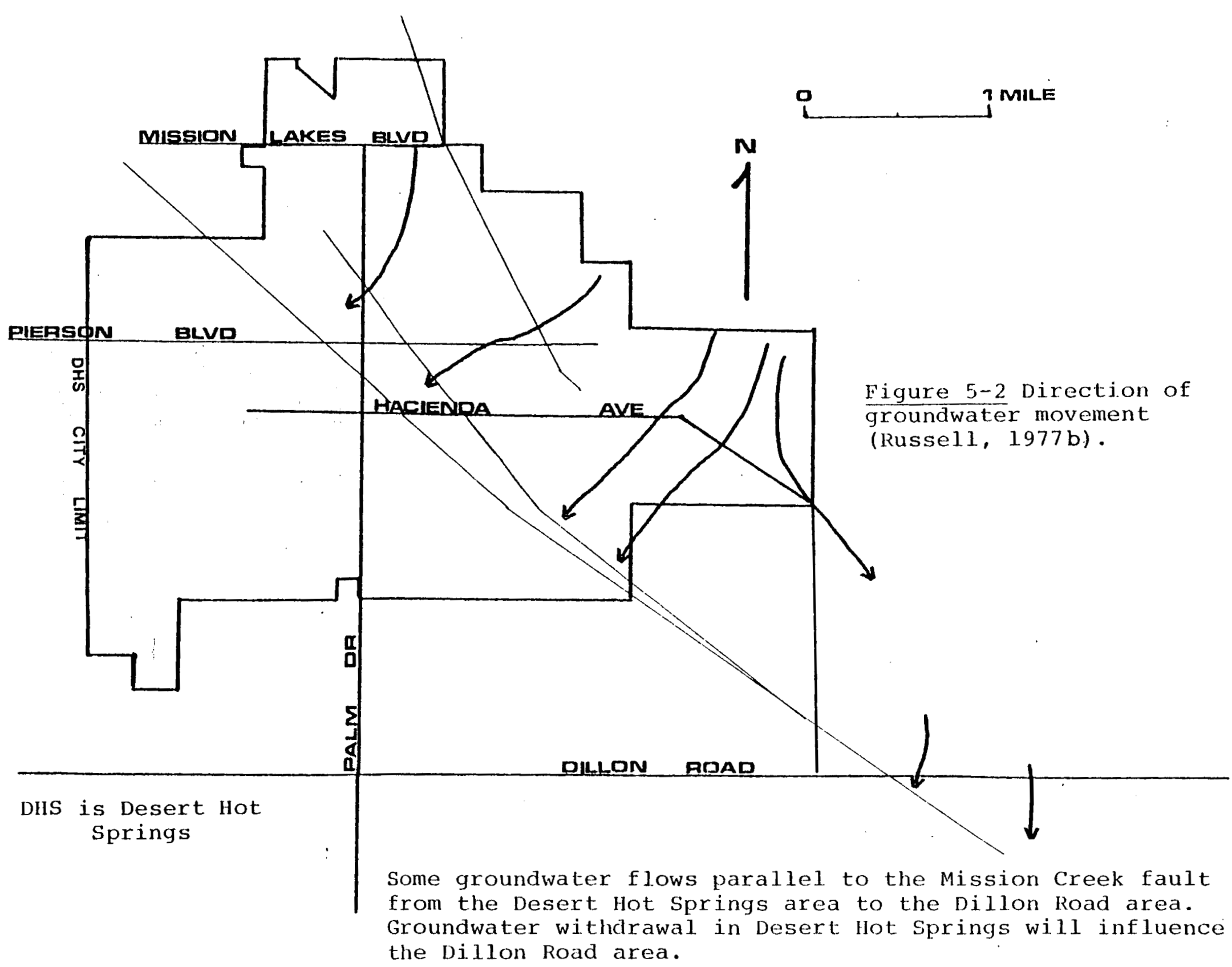


Potential sites for artificial recharge require an area of. (a) low temperature, (b) high permeability, (c) chemical compatibility of hyarothermal fluids and groundwater quality, and (d) groundwater movement toward the withdrawal area.

Low temperatures and high permeabilities are common in the upper Coachella Valley and this factor would not appear to be a limiting factor. Water quality data is not available for enough sites to sufficiently assess the area. The direction of groundwater movement dictates the potential site to be lccated to the north of the Mission Creek fault.

The Blind Canyon area is a potential site for artificial recharge. This site is primarily suggested on the basis of the direction of groundwater movement. The variables pertaining to temperatures, water quality, and permeability are subject to further investigation.

Environmental Impact

The effect of artificial recharge could cause physical and/or chemical impacts. A potential physical problem is an increase in seismic activity of the Blind canyon fault. The primary chemical impact could be groundwater contamination. Artificial recharge in Blind Canyon could increase the seismic activity of the Blind canyon fault. The fault was active in early Recent time (Proctor, 1958, 1968) and its potential seismic activity has not been recorded. The Blind Canyon fault should be studied to determine if the recharge of water would increase the seismic risks associated with the fault movement. 
The recharge of hydrothermal fluids could affect the groundwater quality. A study to determine the compatibility of the hydrothermal fluids and the groundwater would identify any potential problems. The study may indicate that a treatment facility be built to process the fluids prior to recharge.

Further work is recommended to identify the potential physical and/or chemical impacts of artificial recharge on the Desert Hot Springs region. 


\section{CHAPTER VI}

\section{SUMMARY OF CONCLUSIONS}

A summary of the results from the evaluation of the hydrothermal resource of the Desert Hot Springs region is presented in this chapter. These conclusions are based on the discussion of results in Chapter $V$.

\section{Areal Extent}

The delineation of the areal extent of the aquifer system was based on a $90^{\circ} \mathrm{F}\left(32^{\circ} \mathrm{C}\right)$ isotherm. A map with the various isotherms was constructed by using well log temperature data. The total areal extent of the system enclosed by the $90^{\circ} \mathrm{F}$ isotherm was 5.45 square miles.

The Dillon Road area displays higher temperatures than those found within the city limits. Two different avenues of heat may exist for the Desert Hot springs and Dilion Road areas.

The temperature data for wells located in the northwest and southeast portions of the region is not available. The installation of wells in these areas would provide the missing data. 
Statistical Analysis

The statistical analysis has related the hot water in the Desert Hot Springs area to the Blind Canyon fault zone. Those wells closer to the BIind Canyon fault and of greater depth, display higher temperatures. This avenue of heat is responsible for the Desert Hot Springs hydrothermal resource and it implies a separate avenue exists for the Dilion Road area.

The statistical analysis is based on a limited quantity of information. Temperature and depth measurements should be made at more locations in the Desert Hot springs and Dillon Road areas. An attempt should be made to delineate the avenue of heat affecting the Dilion Road area.

\section{Hydraulic Characteristics}

The hydraulic characteristics that were considered for this project were:

(1) transmissivity,

(2) storage coefficient,

(3) boundary conditions,

(4) hydrologic connections, and

(5) storage capacity.

The average transmissivity varies from 15,000 gpd/ft in the north to $43,000 \mathrm{gpd} / \mathrm{ft}$ in the south. The storage coefficient indicates the hydrothermal system is under artesian conditions with an average storativity of $1.5 \times 10^{-4}$. These figures indicate that there is sufficient resource for development beyond private use. 
Detection of boundary conditions and hydrologic connections occur during aquifer tests. None of the test data indicated the presence of a boundary condition; probably the consequence of the low discharge rates and the short period of pumping.

The Two Bunch Palms pump test was the only occasion where a hydrologic connection was detected between two welis, one 80 feet deeper than the other. Data from the Desert Hot Springs County water District combined with the aquifer test data was used to determine that a hydrologic connection does exist over a large portion of the Desert Hot Springs area.

The storage capacity of the Desert Hot Springs region is 500 acre feet. The estimate is based on the areal extent, hycraulic characteristics, and aquifer thickness.

\section{Multiple Aquifer Hypothesis}

No data has been found to substantiate the multiple aquifer hypothesis. A hydrologic connection does exist. between shallow and deep wells with the project region and supports the theory of a single aquifer that is interspersed with layers of varying permeability.

The actual thickness and composition of the reservoir could be obtained by drilling several wells that penetrate the bedrock. This data would provide an accurate estimate to be used to determine the storage capacity for the region. 
Hydrologic Budget Analysis

The hydrologic equation was used to determine the safe yield of the system. Hely and Peck(1964) rad collected data for 30 years for the Colorado Desert and then developed a method to draw maps of annual precipitation, runoff, and evapotranspiration.

The necessary components of the equation were derived using a method that was employed by the IADWP to inventory the groundwater supply of the San Fernando Valiey.

The safest safe yield estimate for the region was 2,100 acre feet. The figure should be considered with regard to magnitude rather than an exact figure.

\section{Direction of Groundwater Movement}

The direction of groundwater movement is from the Iittle San Bernardino Mountains towards the Mission Creek fault zone. Some groundwater moves parallel to the fault zone from the Desert Hot Springs to the Dillon Road areas. The Mission Creek fault zone is an area of discharge for the Desert Hot Springs and Dillon Road areas. An increase in the rate of pumping in the Desert Hot Springs area will decrease the amount of water available in the Dilion Road area.

The major area of recharge is the Iittle San Bernardino Mountains to the northeast of Desert Hot Springs. A potential site for groundwater recharge is the Blind Canyon area, northeast of the city limits. 
The effect of artificial recharge could cause physical andfor chemical impacts dealing with seismicity and groundwater contamination. Further research is recommended to assess these potential problems. 


\section{SELECTED BIBLIOGRAPHY}

Allen, C. R. "San Andreas Fault Zone in Southern California." Geological Society of America Bulletin, Vol. 68, 1957, pp. 315-349.

American Society of Civil Engineers. Ground Water Management. New York: American Society of Civil Engineers, 1961.

Blake, W. P. Explorations in California for Railroad Routes. S. Ex. Document Number 78, 33rd Congress, 2nd Session, 1856 .

Brown, J. S. The Salton Sea Region. USGS Water Supply Paper $497,19 \overline{23 .}$

Erown, R. H. and Ferris, J. G. Methods of Determining Permeability, Transmissibilitv, and Drawdown. USGS Water Supply Paper 1536, 1963.

California Department of Water Resources. Coachella Valley Investigation. California Department of water Resources Bulletin 108, 1964 .

California Division of Water Resources. Groundwater Basins in California. California Division of Water Resources Report Number 3, 1952.

Dermengian, J. H. and Peterson, R. E. "Desert Hot Springs, California." Geothermal Energy Magazine, August, 1976 , pp. 8-13.

Dibblee, T. W. Jr. Geology of the Imperial Valley Region; California. California Division of Mines, Bulletin 170, 1965, pp. 21-28.

Ferris, J. G., Knowles, D. B., Brown, R. H. and Stallman, R. W. Theory of Aquifer Tests. USGS Water Supply Paper 1536, 1963.

Fett, J. - Personal Communication. Geologist. January, 1978.

Hannah, J. The Potential of Low Temperature Geothermal Resources in Northern Califorria. California Division of Oil and Gass, 1975. 
Harnett, D. I. Introduction to Statistical Methods. Addison wesley Publishing, 1975.

Hely, A. G. and Hughes, G. H. Hydrologic Regimen of Salton Sea California. USGS Professional Paper 486-C, 1966.

Hely, A. G. and Peck, E. L. Precipitation, Runoff, and Water Loss in the Lower Colorado River - Salton Sea Area. USGS Professional Paper 486-B, 1964.

Henyey, J. I. and Wasserburg, G. S. "Heat Flow Near Major Stike Slip Faults in California." Journal of Geophysical Research, Vol. 76,1976, Pp. 7924-7946.

Huberty, M. R., Pillsbury, A. F. and Sokoloff, V. P. Hydrologic Studies in Coachella Valley, California. University of California Agricultural Experimental Station, 1948 .

Jet Propulsion Iaboratory. Engineering Analysis of Nonelectric Applications for Geothermal Resources of Desert Hot Springs, California. California. Institute of Technology, 1975.

Johnson, E. Groundwater and Wells. Jchnson Division, UOP Inc. , 1968, 1976.

Kibbey, F. - Dersonal Communication. Desert Hot Springs County Water District. February, 1978.

Lund, J. W. District Utilization -- The International Scene. Geothermal Resources Council, 1978.

Marshall, S. An Evaluation of the Geology, Hydrology, Geochemistry, and Geophysics of Desert Hot Springs, California. Jet Propulsion Laboratory, ig75.

Mendenhall, W. A. and Reinmuth, J. E. Statistics for Management and Economics. Duxbury Press, 1974.

Mendenhali, W. C. Groundwater of the Indio Region. USGS Water Supply Paper 225, 1909.

Miller, G. A. Proposed Water Resources Study of the Upper Coachella Valley Area, California. USGS Open File Report, 1967.

- Narsimhan, T. N. and Witherspoon, P. A. Reservoir Evaluation Tests on RRGE-1 and RRGE-2, Raft River Geothermal Project. Lawrence Berkeley Laboratory, 1977. 
Orcutt, C. R. The Colorado Desert, California. Califcrnia Mines Bureau, Report 10, 1890, pp. 899-919.

Proctor, R. J. "Geology of the Desert Hot Springs Area, Little San Bernardino Mountains, California."

(Unpublished Masters Thesis, UCLA, 1958).

Proctor, R. J. Geology of the Desert Hot Springs -- Upper Coachella Valley Area, California. California Division of Mines and Geology, Special Report 94, 1968.

Pruss, D. E., Olcutt, G. W. and Osterling, W. A. "Areal Geology of a Portion of the Iittle San Bernardino Mountains." Geological Society of America Bulletin, Vol. 70,1959 .

Rantz, S. E. and Eakin, T. E. A Summary of Methods for the Collection and Analysis of Basic Hyarologic Data for Arid Region. USGS Open File Report, 1971.

Reed, M. J. Chemistry of Thermal water in Selected Geothermal Areas of California. California Division of Oil and Gas, 1975 .

Richter, C. F., Allen, C. R. and Nordquist, J. M. "The Desert Hot Springs Earthquakes and Their Tectonic Environment." Seismological Society of America Bulletin, 1958, pp. 315-33I.

Russel1, B. F. "Desert Hot Springs Assessment and Characterization." (Unpublished Report, Jet Propulsion. Laboratory, $1977 \mathrm{a})$.

Russeil, B. F. "Two Bunch Palms Eump Test." (Unpublished Report, Jet Propulsion Laboratory, 1977b).

Russell, B. F. "A Reconnaissance Study of the Hydrothermal Resources of Desert Hot Springs, California."

(Unpublished Report, California Energy Comission,.. 1978).

Troxell, H. C. Hydrology of Western Riverside County, California. Riverside Flood Control and Water District Report, 1948 .

Tyley, S. J. Analog Model of the Groundwater Basin of the Upper Coachella Valley, California. USGS Open File Report, 1971.

Vaughn, E. E. "Geology of the San Bernardino Mountains North of San Gorgonio Pass." University of California Geological Bulletin, Vol. 13, 1922, pp. 319-416. 
Witherspoon, P. A., Javandel, S. P. and Freize, R. A. Interpretation of Aquifer Storage Conditions from Water Pumping Tests. American Gas Association, 1967.

White, D. F. and Williams, D. I. Assessment of Geothermal Resources of the United States. USGS Circular 726, 1975 . 
APPENDIX A

Hydrologic Budget Analysis 
TABLE 1

MEAN ANNUAL PRECIPITATION

A.

\begin{tabular}{|c|c|c|c|c|}
\hline $\begin{array}{l}\text { Isohyet } \\
\text { (inches). }\end{array}$ & $\begin{array}{c}\text { Area } \\
\text { Enclosed } \\
\text { (sq. miles) }\end{array}$ & $\begin{array}{c}\text { Net Area } \\
\text { Enclosed } \\
\text { (sq. miles) }\end{array}$ & $\begin{array}{c}\text { Average } \\
\text { Precipitation } \\
\text { (inches) }\end{array}$ & $\begin{array}{l}\text { Precipitation } \\
\text { Volume } \\
\text { (acres) }\end{array}$ \\
\hline
\end{tabular}

$\begin{array}{rrrrr}10.00 & 67.70 & 1.25 & 11 & 13.75 \\ 8.00 & 66.45 & 19.87 & 9 & 178.83 \\ 6.00 & 46.58 & 44.72 & 7 & 313.04 \\ 4.00 & 1.86 & 1.86 & 5 & 9.30\end{array}$

$\begin{array}{cc}\text { Total } 67.70 & 514.92 \\ \begin{array}{c}\text { Average Precipitation }=514.92 / 67.70 \\ \text { precipitation }\end{array} & \text { or } 7 / 61 " \text { mean annual }\end{array}$
precipitation

B.

MEAN ANNUAL RUNOFF

\begin{tabular}{lcccc}
\hline $\begin{array}{c}\text { Isogram } \\
\text { inch) }\end{array}$ & $\begin{array}{c}\text { Area } \\
\text { (sq.iosed } \\
\text { miles) }\end{array}$ & $\begin{array}{c}\text { Net Area } \\
\text { Enclosed } \\
\text { (sq. miles) }\end{array}$ & $\begin{array}{c}\text { Average } \\
\text { Precipitation } \\
\text { Iinches) }\end{array}$ & $\begin{array}{c}\text { Precipitation } \\
\text { Volume } \\
\text { (acres) }\end{array}$ \\
\hline 1.0 & 67.70 & 1.24 & 3.0 & 3.72 \\
0.5 & 66.46 & 46.58 & 0.75 & 34.94 \\
0.02 & 19.88 & 16.77 & 0.26 & 4.36 \\
0.00 & 3.11 & 3.11 & 0.01 & 0.03 \\
& \multicolumn{5}{c}{ Total } & 67.70 & & 43.05
\end{tabular}

Average Surface Runoff $=43.05 / 67.70$ or $0.64 "$ mean annual surface runoff 
TABLE 2 - ACRE FEET COMPUTATIONS

PRECIPITATION = SURFACE RUNOFF + INFILTRATION + EVAPOTRANSPIRATION

\section{Precipjtation}

$7.61 "$ fell over $67.70 \mathrm{sq}$. miles or

$\left(0.634^{\prime}\right)\left(67.70 \mathrm{sq}\right.$. miles) $\left(2.79 \times 10^{7} \mathrm{ft}^{2} / \mathrm{sq} \cdot \mathrm{mile}\right)=1.198 \times 10^{9} \mathrm{ft}^{3}$ or $2.749 \times 10^{4}$ ACRE FEET

\section{Surface Runoff}

$0.64 "$ of runoff over $67.70 \mathrm{sq}$. miles or

$\left(0.05^{\prime}\right)\left(67.70 \mathrm{sq}\right.$. miles) $\left(2.79 \times 10^{7} \mathrm{ft}^{2} / \mathrm{sq} \cdot \mathrm{mile}\right)=1.00 \times 10^{8} \mathrm{ft}^{3}$ or $2.30 \times 10^{3}$ ACRE FEET

\section{Evapotranspiration}

6.0" mean annual evapotranspiration or

$\left(0.50^{\prime}\right)\left(67.70 \mathrm{sq}\right.$. miles) $\left(2.79 \times 10^{7} \mathrm{ft}^{2} / \mathrm{sq} \cdot \mathrm{mile}\right)=9.44 \times 10^{8} \mathrm{ft}^{3} \mathrm{or}$ $2.168 \times 10^{4}$ ACRE FEET

INFILTRATION = PRECIPITATION - SURFACE RUNOFF - EVAPOTRANSPIRATION

INFILTRATION $=27,490-2,168-21,680$ OR

INE ILTRATION $=3,500$ ACRE FEET 


\section{APPENDIX B}

Aquifer Tests 


\section{TABLE I}

\section{SCHEDULE FOR WATER LEVEL MEASUREMENTS}

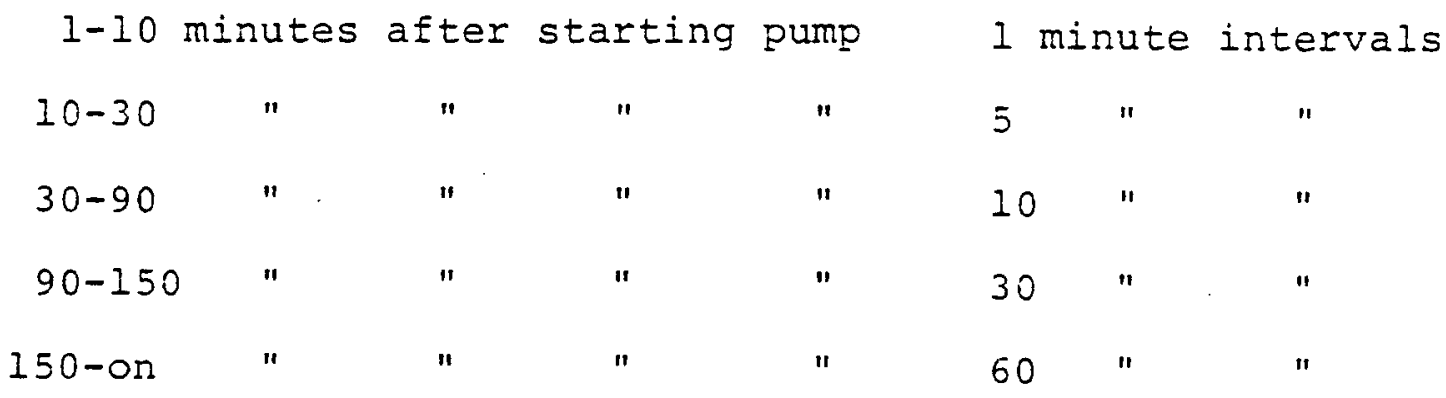


Time since pumping beçan, $t$, minutes

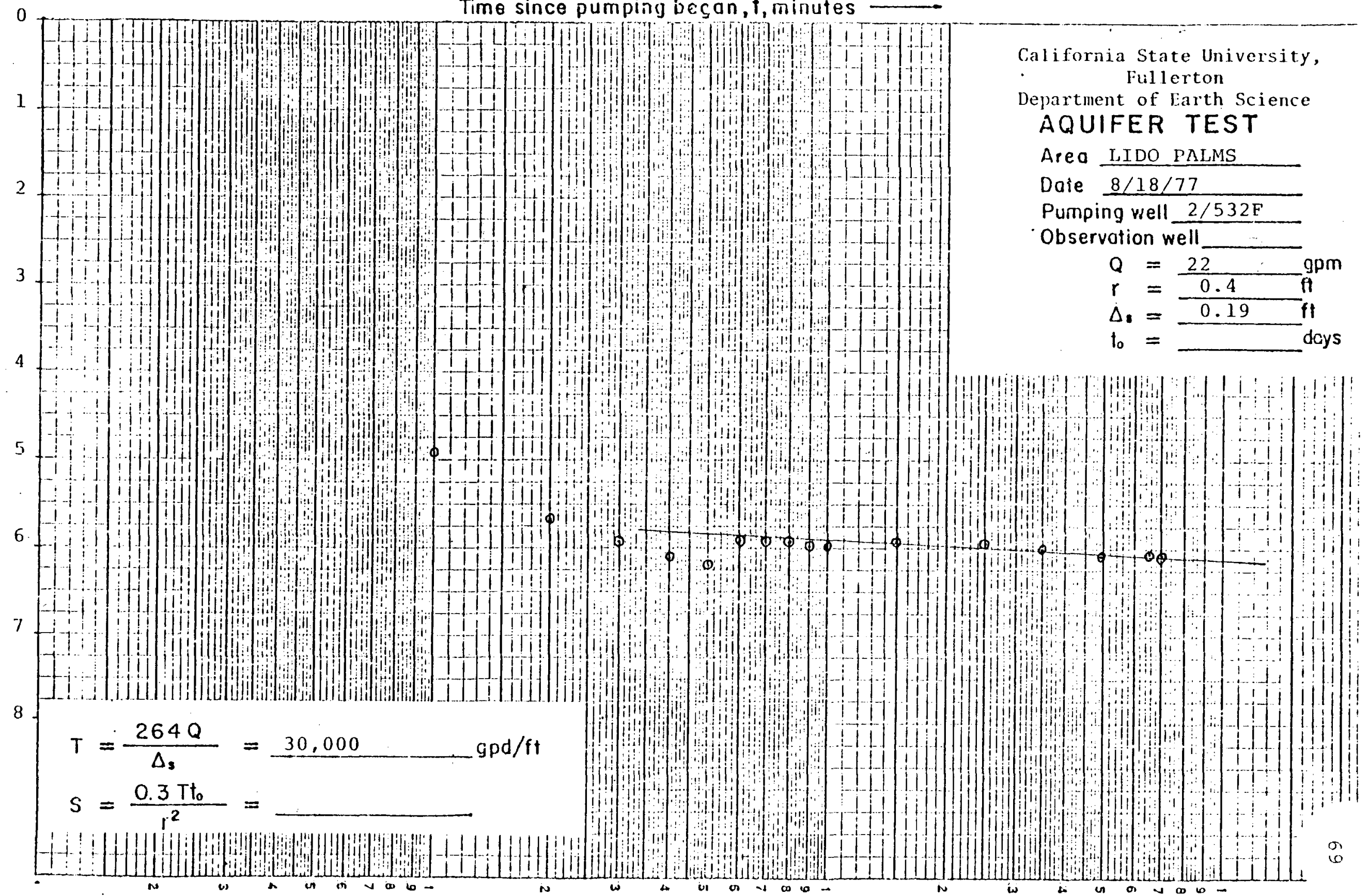


Time since pumping beçan, $t$, minutes

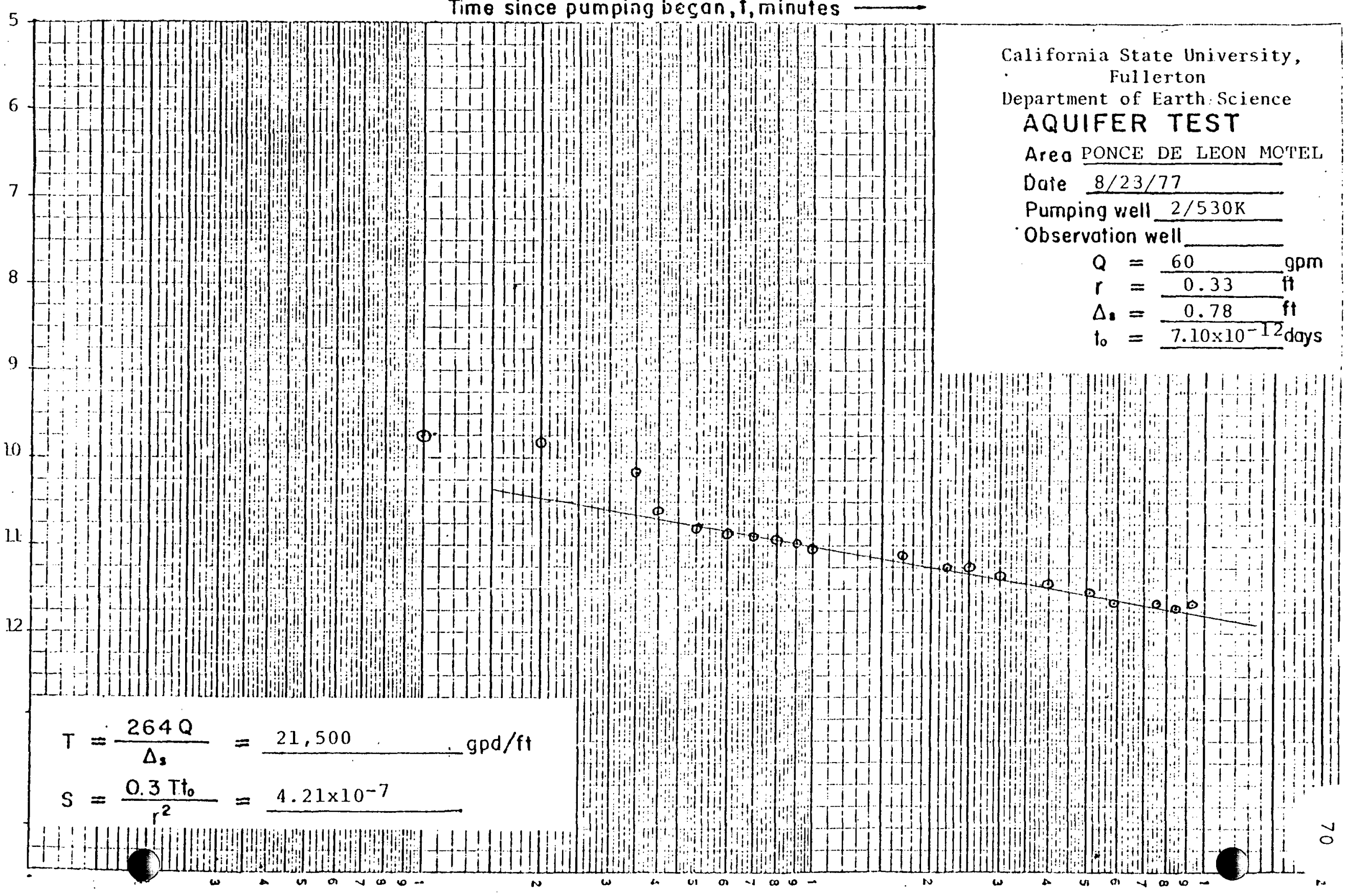


Time since pumping becan, $t$, minutes

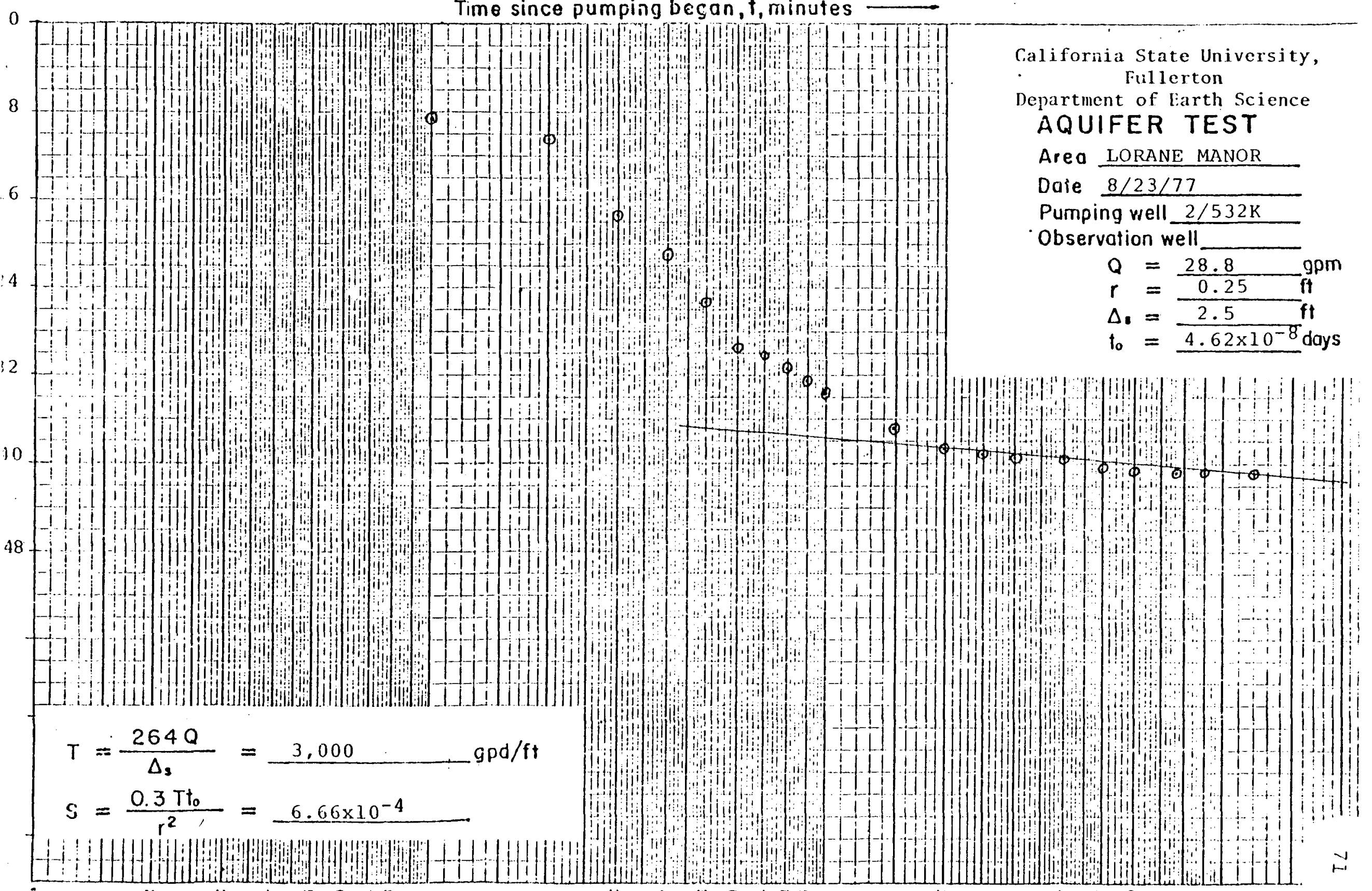


TIME RECOVERY

Time since pumping stopped, minutes

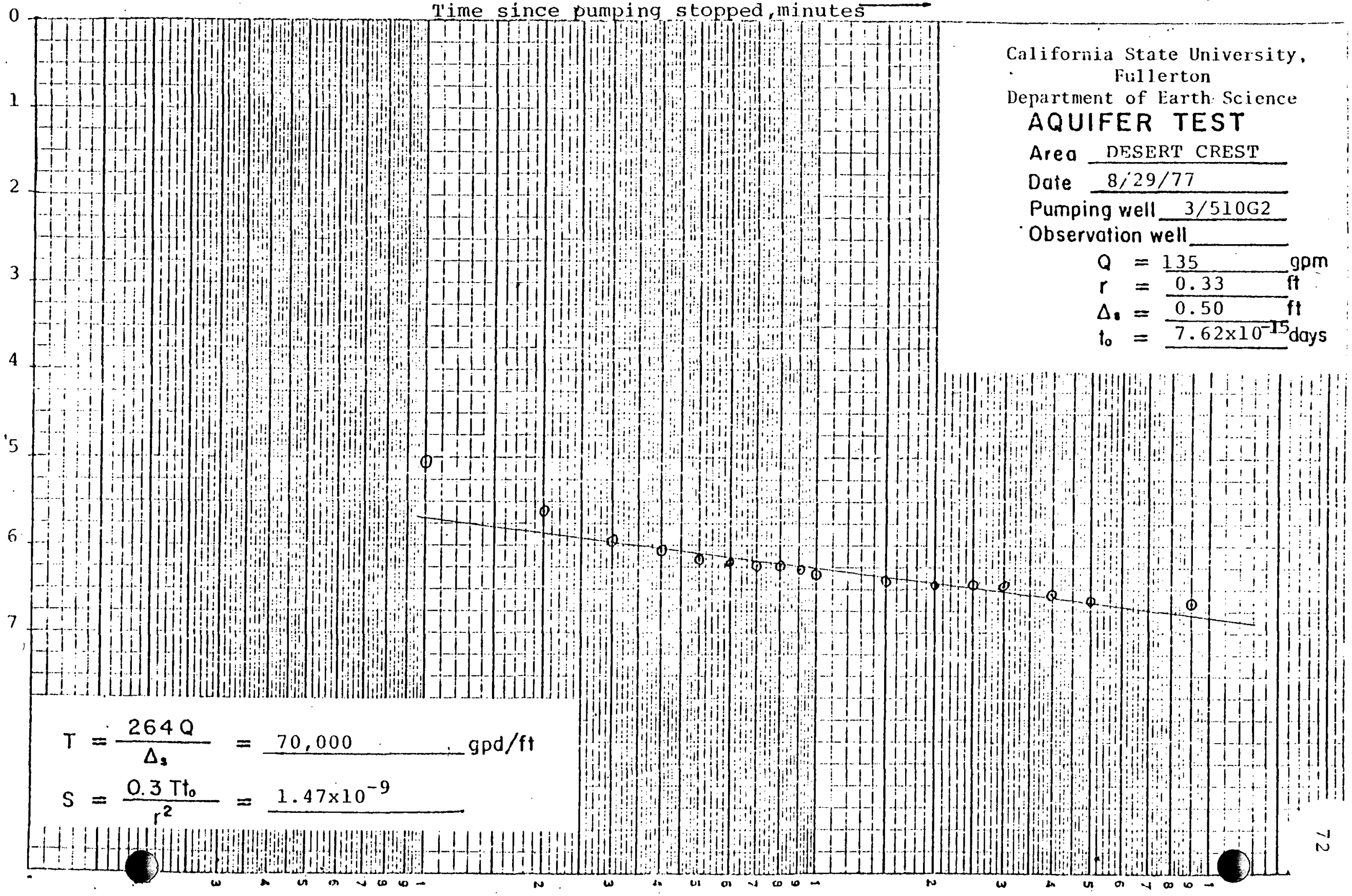


Time since pumping becan, $t$, minutes

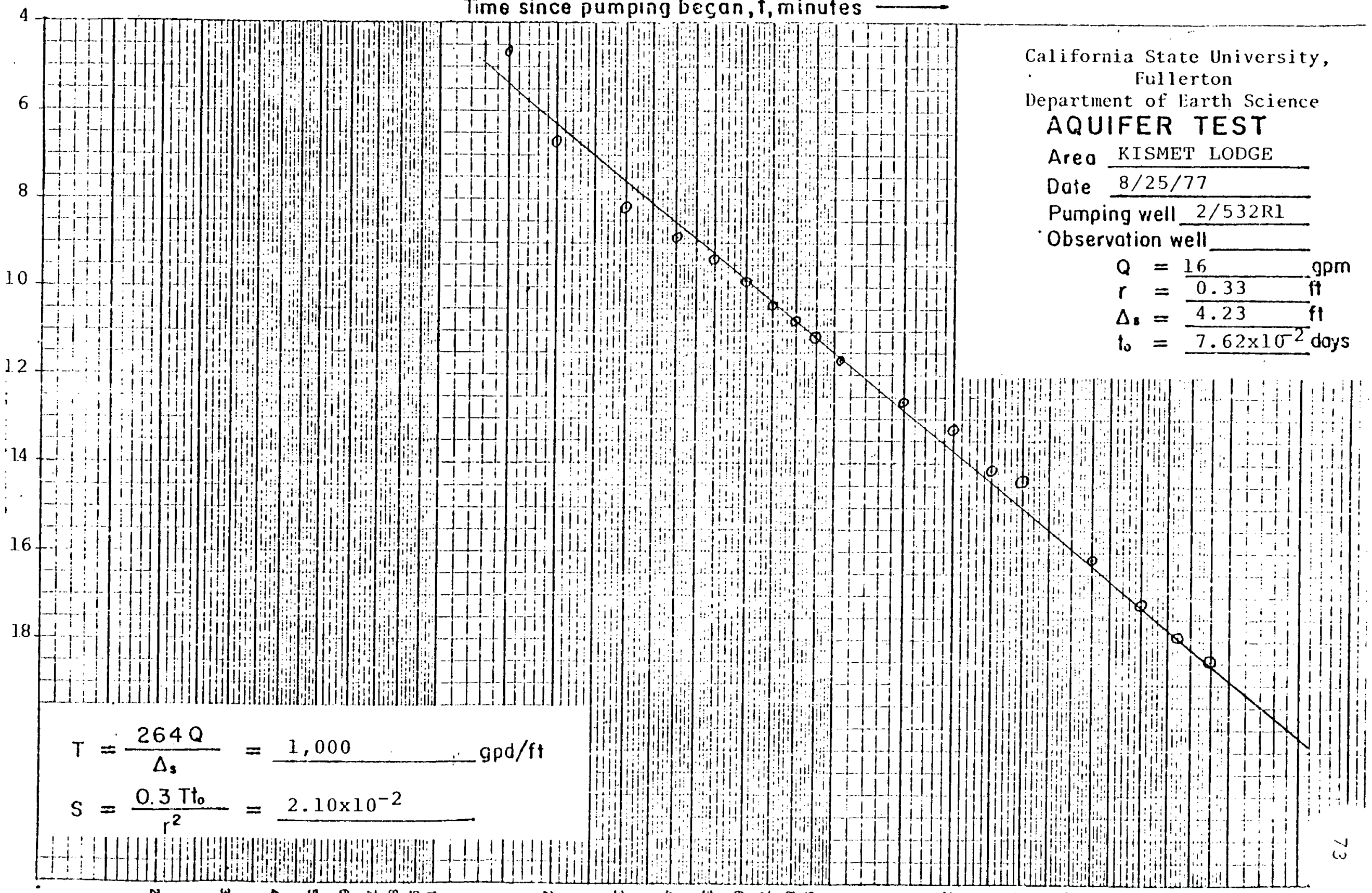


Time since pumping began, $t$, minutes

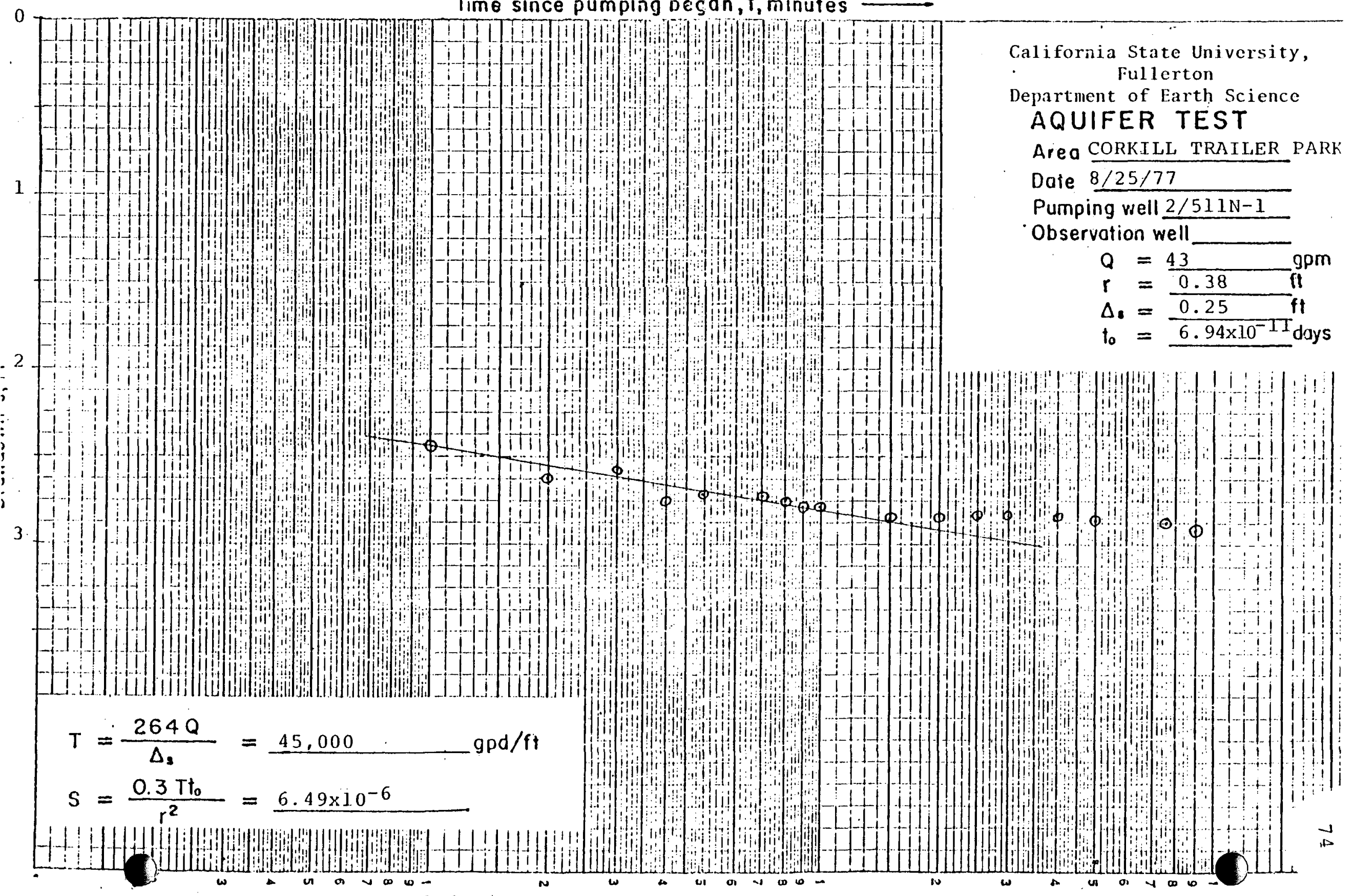


Time since pumping began, $t$, minutes

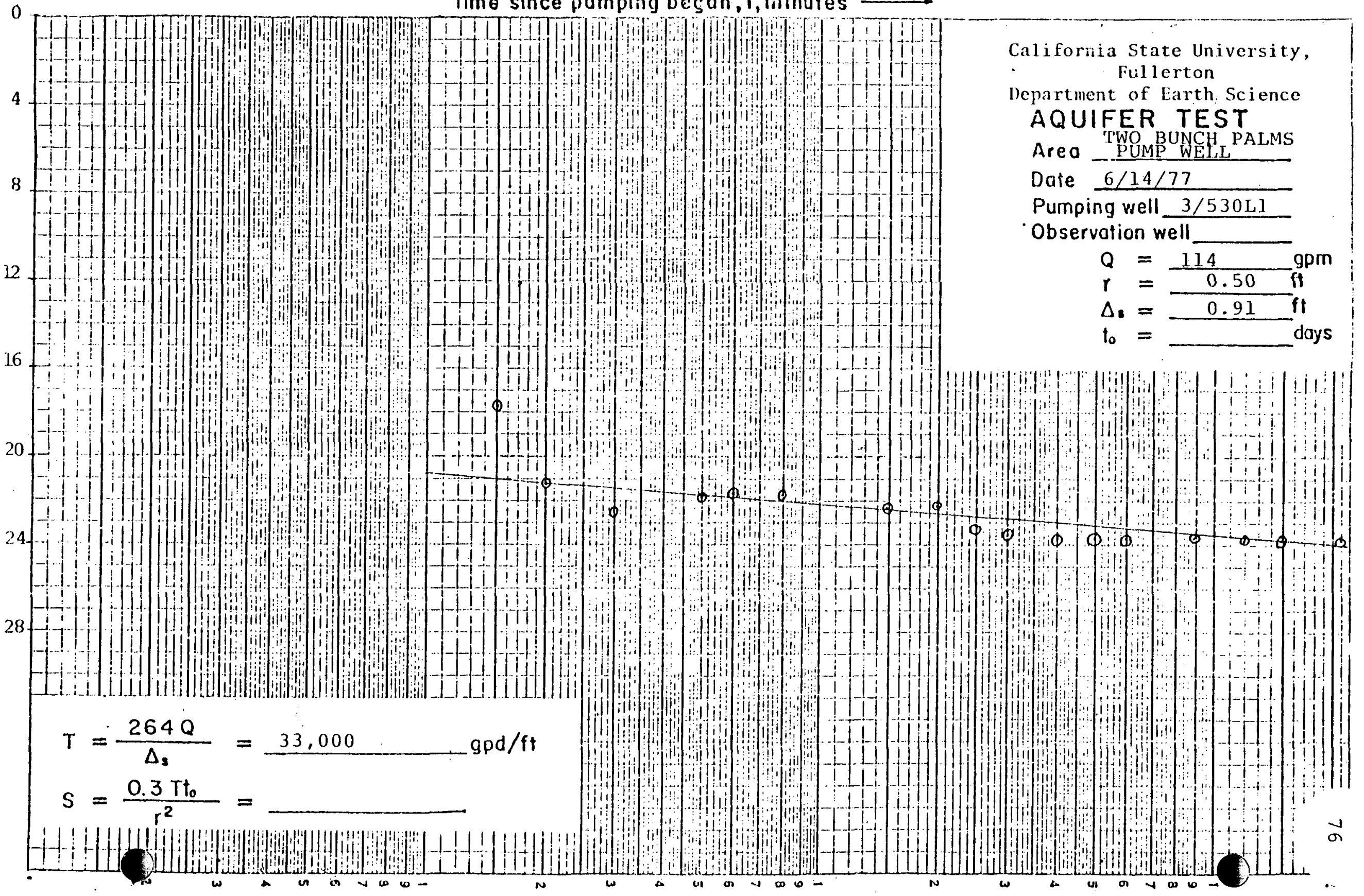


Time since pumping becan, $t$, minutes

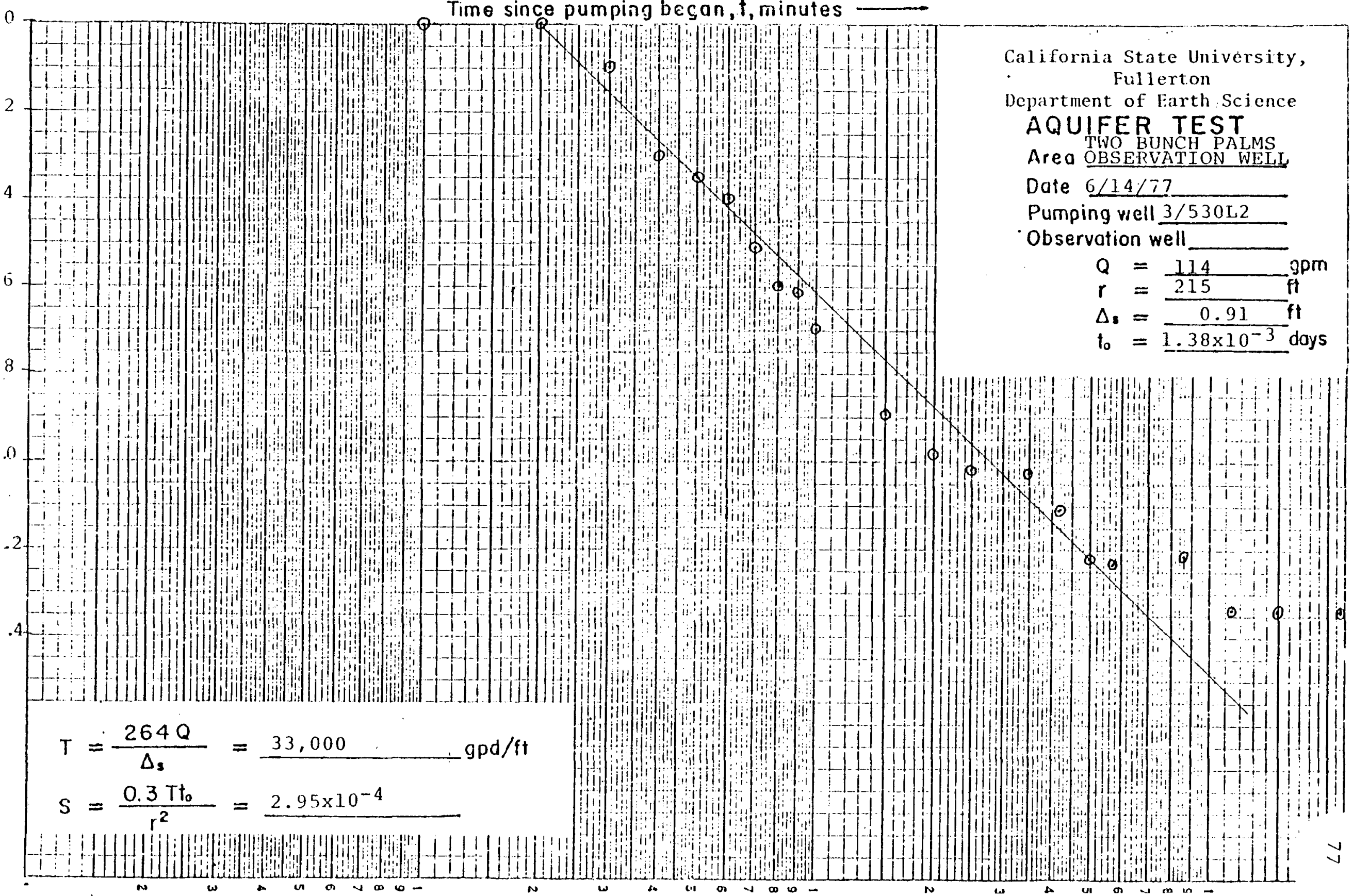

